Fordham Law School

FLASH: The Fordham Law Archive of Scholarship and History

Faculty Scholarship

2019

We the People: These United Divided States

Catherine Powell

Follow this and additional works at: https://ir.lawnet.fordham.edu/faculty_scholarship

Part of the Law Commons 


\title{
We The PeOple: These United Divided STATES ${ }^{1}$
}

\author{
Catherine Powell +
}

TABLE OF CONTENTS

INTRODUCTION

I. Adapting Ely's Notion of Correcting Political Market Failure........ 2697

A. Immigrants' Rights: The Problem of Minority Underrepresentation ... 2698

B. Climate Policy: The Problem of Regulatory Capture by Influential

Economic Minorities.

C. Immigration and Climate Policies: Informational Asymmetries and Markets Failures.

D. Federalism and Transnationalism as Correctives to Political Market Failure

E. International Law as a Corrective to Political Market Failure. 2712

F. Limitations of this Approach

1 This title draws inspiration-and quotes from - the song, Seriously, performed on This American Life, written by Sara Bareilles and performed by Leslie Odom, Jr. This American Life, Seriously -This American Life, Sara Bareilles, and Leslie Odom, Jr., YouTUBE (Oct. 28, 2016), https://www.youtube.com/watch?v=hI8TCA3fJcs ("In a history plagued with incredible mistakes-Still, I pledge my allegiance to these United divided States.”).

$\dagger$ Professor of Law, Fordham University School of Law. For helpful comments and conversation on earlier drafts, I am grateful to Nestor Davidson, Rose Cuison-Villazor, Martin Flaherty, Jennifer Gordon, Clare Huntington, and Jaya Ramji-Nogales. I am also grateful to participants in the Immigration Law Teachers and Scholars Workshop, Yale Law School Schell Center for Human Rights Workshop, and Fordham Law Faculty Workshop, as well as participants at conferences where I presented much earlier drafts of the Article at the University of Pennsylvania, Perry World House, as well as at the International Society of Public Law Annual Meeting at Hong Kong University Faculty of Law. Further thanks are due to my superb research assistants, Mary Katherine Cunningham, Glen Dalakian II, Brianna Discenza, Leanna Fornelli, Caitlin Hickey, Aryian Kohandel-Shirazi, Katri Stanley, and Leena Widdi. 
II. Climate Change Federalism

2715

A. The Shift in Global Environmental Governance at the Global Level ... 2717

1. The Need for Reform and Overview of the Shift ..... 2718

2. The Traditional Regulatory Approach: From Rio to Kyoto .... 2721

3. The Transition from the Regulatory to Catalytic Approach ... 2723

4. The Catalytic Approach: Paris Agreement and Beyond 2725

5. U.S. Paris Commitments and Trump's Threatened Withdrawal2727

B. "We the People" and Climate Change at the Domestic Level 2731

1. States and Localities to Trump: "Get Out of the Way" ............. 2732

2. Iterative Federalism and Climate Change ................................. 2735

C. Applying Lessons from Global Governance to Federalism ................... 2742

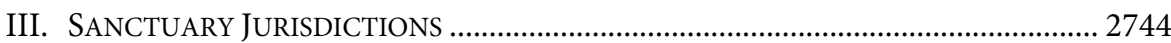

A. Shortcomings of the International Framework on Immigrants ............ 2745

B. Four Waves of "Sanctuary" Policies........................................................ 2747

C. "We the People" and "Sanctuary" Policies ............................................... 2754

1. Typology of Sanctuary Policies Aimed at Disentanglement ... 2754

2. What Motivates Sanctuary Policies and to What Extent Do They Address the Minority Underrepresentation Problem? ............ 2757

a. Preserving Local Control over Criminal Justice............. 2758

b. Enhancing Community Trust and Community Policing2759

c. Averting Unlawful Arrests ................................................. 2761

d. Securing Equal Protection ................................................ 2761

e. Encouraging Diversity and Inclusivity .......................... 2762

D. The Treatment of Immigrants as a Tipping Problem ............................ 2763

CONCLUSION: “NOT YOUR FATHER’s FEDERALISM”.................................................... 2766 


\section{INTRODUCTION}

In the wake of President Trump's announcement that he will withdraw the United States from the 2015 Paris Agreement on climate change, then-California Governor Jerry Brown called on the President to fight climate change or to "get out of the way" while the rest of the world works to reduce emissions and invest in clean energy. ${ }^{2}$ Similarly, former New York City Mayor Michael Bloomberg-now a United Nations (U.N.) Special Envoy for Cities and Climate Change-said, "If Washington won't lead, then mayors and governors will." 3 Indeed, Trump's threat to withdraw has not only been met with widespread criticism and derision abroad and at home, but as this Article examines, has also sparked more consequential action, with numerous U.S. mayors and governors pledging to meet emissions-reductions goals outlined in the agreement. 4

A similar dynamic is playing out in the context of immigration. In the aftermath of Trump's promise to "end" sanctuary jurisdictions by cutting them off from federal funding, ${ }^{5}$ a growing number of state and local governments are refusing to participate in the enforcement of federal immigration law by disentangling their criminal justice systems from the federal immigration regime. This disentanglement process began well before the Trump presidency, but it has accelerated by some measures since the 2016 election. ${ }^{6}$ Rather than using an era of mass incarceration to facilitate a new era of mass deportation, these jurisdictions have adopted a set of reforms to protect immigrants from deportation when they interact with the criminal justice system. ${ }^{7}$

2 The Latest: Jerry Brown to Trump: "Get Out of the Way", Associated PRESS (Dec. 12, 2017), https://www.apnews.com/1098c54326f14a61b149e4e2030a40f4 [https://perma.cc/ZA6GHG25] [hereinafter Brown to Trump].

3 Jonathan Watts, Alternative US Group Honouring Paris Climate Accord Demands 'Seat at the Table', GUARDIAN (Nov. 11, 2017, 10:55 AM), https://www.theguardian.com/environment/ 2017/nov/11/alternative-us-group-honouring-paris-climate-accord-demands-seat-at-the-tablebonn [https://perma.cc/3L8M-3F3W].

4 See discussion infra Section II.B.1.

5 Exec. Order No. 13768, 82 Fed. Reg. 8799 (Jan. 25, 2017).

6 For a discussion of trends in disentanglement policies since the 2016 election, see infra Part III.

7 See generally Christopher N. Lasch et al., Understanding "Sanctuary Cities", 59 B.C. L. REV. 1703 (2018) (making this point in the sanctuary cities context). 
Climate change and sanctuary jurisdictions are but two areas that reflect the conflict between state and local progressivism and federal conservativism. Yet climate and immigration policy are somewhat unique in that they represent case studies of federalism conflicts that are inherently transnational. 8 While federalism is a staple of legal scholarship, this Article brings a new lens to this old debate: international law theory. Drawing on international law and its close cousin, international relations theory, ${ }^{9}$ I examine how-now, more than ever-federalism matters that are inherently transnational can be better understood by applying analysis at the border of constitutional and international law.10 As an advantage of taking a trans-substantive

8 Of course, state, county, and local governments have been policy innovators on a range of other issues that are beyond the scope of this Article, including marriage equality, health care, gun control, marijuana legalization, and living wage protections. I am limiting the focus to climate change and sanctuary jurisdictions, as both are inherently transnational and relate to the broader themes of this Article concerning sovereignty and international law.

It is also worth noting that innovation by subnational governments promotes not only progressive goals, but conservative aims as well, such as prohibitions on sanctuary jurisdictions (as with SB4 in Texas), restrictions on marriage equality (before the Supreme Court protected marriage equality), limitations on transgender rights (as in North Carolina), and religious exemptions to sexual identity and/or gender identity antidiscrimination protections. For an important discussion of state anti-sanctuary policies, see Pratheepan Gulasekaram, Rick Su \& Rose Cuison Villazor, Anti-Sanctuary \& Immigration Localism, 119 COLUM. L. REV. 837 (2019).

9 This Article enlists both international law and its cousin from political science, international relations theory, as the two are quite interconnected in international law scholarship and practice. As Anne-Marie Slaughter famously notes, "Just as constitutional lawyers study political theory, and political theorists inquire into the nature and substance of constitutions, so too should two disciplines that study the laws of state behavior seek to learn from one another." Anne-Marie Slaughter Burley, International Law and International Relations Theory: A Dual Agenda, 87 AM. J. INT'L L. 205 (1993) (noting that "the postulates [of international relations theory]... concerning patterns... in state behavior must afford a foundation and framework for legal efforts to regulate that behavior.").

10 This Article builds on an earlier generation of federalism scholarship (prior to 2000) by international law scholars (including my own earlier work) but applies a new angle. For a summary and discussion of this earlier transnational federalism scholarship, see, for example, Catherine Powell, Dialogic Federalism: Constitutional Possibilities for Incorporation of Human Rights Law in the United States, 150 U. PA. L. REV. 245 (2001); Peter J. Spiro, Foreign Relations Federalism, 70 U. Colo. L. REV. 1223 (1999); and Peter J. Spiro, Learning to Live with Immigration Federalism, 29 CONN. L. REV. 1627 (1997).

Other more recent federalism controversies (following 2000) have international dimensions as well, including the debates over marijuana legalization (given international drug cooperation and agreements); guns (given the flap over the U.N. Arms Trade Treaty, which critics claimed would lead to additional registration requirements for small arms); and the 
approach in considering federalism, climate change and sanctuary policy provide a helpful contrast with one another, because while international law in the climate area is gaining traction, international protections on immigrants' rights are weak to nonexistent.

At the same time, the climate and sanctuary case studies represent similarities in that both can be understood within the context of the constitutional law scholarship on backlash, even though the response here is to White House policies, not court decisions. ${ }^{11}$ But rather than view backlash as destructive, constitutional law scholars might view it as constitutive of normative progress-as critically important for sharpening, defining, and deepening traction for law reform. ${ }^{12}$

treatment of foreign nationals on death row in states where the death sentence is available (in light of international protections under the Vienna Convention on Consular Relations (VCCR)). See, e.g., Wells C. Bennett \& John Walsh, Marijuana Legalization Is an Opportunity to Modernize International Drug Treaties, BRoOKINGS (Oct. 15, 2014), https:// www.brookings.edu/research/marijuana-legalization-is-an-opportunity-to-modernizeinternational-drug-treaties [https://perma.cc/ZWX7-XPNA]; see also Mike Weisser, What Does the New UN Small Arms Treaty Really Say?, HuffPost (Nov. 25, 2013, 11:04 AM), https:// www.huffingtonpost.com/mike-weisser/un-small-arms-treaty_b_4337810.html [https:// perma.cc/BCW8-ZTET]; Paul Schiff Berman, Federalism and International Law Through the Lens of Legal Pluralism, 73 Mo. L. REV. 1149 (2008) (discussing the interaction of federalism and international law in the context of the VCCR). Interestingly, in contrast to state and local initiatives to mitigate climate change or protect immigrants, the trend in state and local initiatives that have sought to legalize marijuana are not in sync with international drug treaties. See Bennett \& Walsh, supra.

11 Cf. William N. Eskridge, Jr., Pluralism and Distrust: How Courts Can Support Democracy by Lowering the Stakes of Politics, 114 YALE L.J. 1279, 1326 (2005) (arguing that courts should avoid rulings like Roe v. Wade and Bowers $v$. Hardwick because of backlash, where Roe forced traditionalists to exit American politics, while Bowers prevented gays from entering it); Michael J. Klarman, How Brown Changed Race Relations: The Backlash Thesis, 81 J. AM. HIsT. 81 (1994) (analyzing backlash to Brown); Cass R. Sunstein, Three Civil Rights Fallacies, 79 CALIF. L. REV. 751, 766 (1991) (discussing backlash against Roe v. Wade and attributing the birth of the Moral Majority to the case). See also Susan Faludi, Backlash: The Undeclared War Against AMERICAN WOMEN 230-31 (1991).

12 Cf. Robert Post \& Reva Siegel, Roe Rage: Democratic Constitutionalism and Backlash, 42 HARV. C.R.-C.L. L. REV. 373 (2007). Responding to Eskridge, Klarman, and Sunstein, supra note 11, Post and Siegel propose a theory on democratic constitutionalism to rebut concerns about backlash, noting:

Although the costs of backlash are well recognized, democratic constitutionalism identifies certain underappreciated benefits of backlash. Backlash can promote constitutional solidarity and invigorate the democratic legitimacy of constitutional interpretation. 
Moreover, such federalism conflicts call for more serious attention to the broader international context, not only because they are inherently transnational, but also because these conflicts represent responses to the types of problems John Hart Ely aptly described to justify court intervention when political markets systematically malfunction. ${ }^{13}$ This Article adapts Ely's concept. While his theory focused on judicial review (horizontal separation of powers), I use his concept of political market failure as a basis for a theory of federalism (vertical separation of powers).

In particular, I examine two forms of political market failures ${ }^{14}$ to explain-and support-a turn to lawmaking from below (and where possible, from above) the level of nation-state. The first type of political market failure this Article explores-in the immigration contextresults when minorities are not only underrepresented, but also systematically locked out of political power, 15 leading to a "tyranny of the majority." 16 The second form of political market failure I examinein the climate context-represents the exact opposite problem: here, influential minorities (in this case, the fossil fuel industry and other powerful economic interests) "dominate the political process, and the

Post \& Siegel, supra, at 376.

13 John Hart Ely, Democracy and Distrust: A Theory of Judicial Review 103 (1980). Ely famously notes:

Malfunction occurs when the process is undeserving of trust, when (1) the ins are choking off the channels of political change to ensure that they will stay in and the outs will stay out, or (2) though no one is actually denied a voice or a vote, representatives beholden to an effective majority are systematically disadvantaging some minority out of simple hostility or a prejudiced refusal to recognize commonalities of interest, and thereby denying that minority the protection afforded other groups by a representative system.

Id.

$14 \mathrm{I}$ am adapting these two types of political market failures from an analysis of five forms that justify judicial intervention, identified by Niels Petersen. Niels PETERSEN, PROPORTIONALITY AND JUdiCIAL ACTIVISM: FUNDAMENTAL RIGHTS ADJUDICATION IN CANADA, GERMANY, AND SOUTH AFRICA 13-34 (2017) (applying John Hart Ely by elaborating on various types of political market failures justifying judicial intervention). Following Ely, Petersen focuses on judicial intervention, while my focus is on federalism. For discussion of other scholars who have extended the market analogy to the political process, see infra Part I.

15 See ELY, supra note 13, at 103.

16 Alexis de Tocqueville, Democracy in America 183 (Harvey C. Mansfield \& Delba Winthrop trans., 2000) (1835). 
public has to be protected against legislative capture" 17 or (as with climate policy) regulatory capture (within the executive branch).

Bringing international law theory to federalism debates, this Article argues that federal law can be shaped from above and below-not only as a check on federal power, but also as a way to address entrenched market failures in our national political process. With regards to lawmaking from above, as discussed infra in Section III.A, while an earlier wave of sanctuary policies explicitly invoked international law, current policies do not ${ }^{18}$-as mentioned, an important contrast with the climate context. In terms of lawmaking from below, federalism can be either cooperative or uncooperative. ${ }^{19}$ But, the idea of divided government is not simply structure for structure's sake, as the notion of "dual sovereignty" might imply, but, ultimately, as the Framers envisioned, it is about preserving popular sovereignty-to maintain a government accountable to the People and that respects individual rights. ${ }^{20}$ At the same time, the raison d'etre for international law is, inter alia, to address collective action failures (such as climate change) and to bring international scrutiny to questions once considered the exclusive

17 PETERSEN, supra note 14, at 19.

18 As noted infra in Section III.B, an earlier wave of city ordinances explicitly invoked the Convention Relating to the Status of Refugees (and focused on political refugees-in contrast to economic immigrants-to the extent the distinction holds). While current policies do not invoke international law, at least some sanctuary jurisdictions justify their protective policies based on commitment to values that are protected in international human rights lawincluding protections against racial profiling, measures to sustain inclusive communities, human dignity, family rights, due process, and fairness.

19 Jessica Bulman-Pozen \& Heather K. Gerken, Uncooperative Federalism, 118 YALE L.J. 1256 (2009). For a discussion of the "cooperative federalism structure of [the] EPA's recent Clean Power Plan" along with other cooperative examples, see generally Kirsten H. Engel, Democratic Environmental Experimentalism, 35 UCLA J. ENVTL. L. \& POL'Y 57 (2017). For a conceptual discussion of uncooperative federalism as illustrative of the value of "disloyalty," see generally Heather K. Gerken, Exit, Voice, and Disloyalty, 62 DUKE L.J. 1349 (2013) (adapting the ideas from Albert O. Hirschman, EXIT, Voice, AND LOyAlty: RESPONSES TO DECLINE IN FIRMS, ORGANIZATIONS, AND STATES (1970)).

20 As James Madison said of the checks and balances built into our constitutional system, to protect rights, "[a]mbition must be made to counteract ambition." THE FEDERALIST No. 51 (James Madison). 
domain of the nation-state (such as human rights, including minority rights, the very concern that is at the heart of Ely's theory). ${ }^{21}$

However, constitutional and international law scholars often talk past each other, failing to draw on the insights from the other field. Within constitutional law, a rethinking is underway to push constitutional theorists to reconceptualize the way we conceive of federalism. For example, as Heather Gerken argues that since sovereignty was long ago declared dead, ${ }^{22}$ we need a new intellectual framework- "Federalism 3.0"-that rejects the notion of states and the federal government as dual sovereigns confined to separate spheres, ${ }^{23}$ and instead recognizes that they now "regulate shoulder-to-shoulder" 24 and often influence each other. In this rethinking, however, federalism scholars have yet to closely examine the role of international law in eroding the traditional notion of government sovereignty and the relevance of this for the reconceiving of federalism.

Conversely, international law and international relations scholars have examined the disaggregation of sovereignty, 25 but theorists have not adequately applied these lessons to new questions concerning federalism. Much ink has been spilled over how international legal developments have effectively pierced the traditional veil of sovereignty in areas such as trade, refugee law, antitrust regulation, humanitarian

21 U.N. Charter art. 1. Along with maintaining international peace and security more broadly, the U.N. Charter states that the primary purposes of the U.N. includes achieving "international cooperation in solving international problems of an economic, social, cultural, or humanitarian character, and in promoting and encouraging respect for human rights and for fundamental freedoms for all without distinction as to race, sex, language, or religion[.]" Id. 9.

22 Heather K. Gerken, Federalism 3.0, 105 CALIF. L. REV. 1695, 1698 (2017) (noting "sovereignty has been declared 'dead' so many times").

23 Id. at 1696-98 (calling for an updated approach to federalism that moves beyond the constitutional theory constituted in the wake of the New Deal, reinscribing accounts of state sovereignty with those of state autonomy (Federalism 1.0) and moving past the rights/structure dichotomy that emerged in the debate over the legacy of the Civil Rights Era (Federalism 2.0)).

24 Id. at 1722.

25 See, e.g., Harold Hongju Koh, Why Transnational Law Matters, 24 PENN. ST. INT'L L. REV. 745 (2006); Janet Koven Levit, Bottom-Up International Lawmaking: Reflections on the New Haven School of International Law, 32 YALE J. INT'L L. 393 (2007); Anne-Marie Slaughter, Disaggregated Sovereignty: Towards the Public Accountability of Global Government Networks, 39 Gov't \& Opposition 159 (2004); Global Urban Justice: The Rise of Human Rights Cities 9 (Barbara Oomen et al. eds., 2016). 
law, and human rights. ${ }^{26}$ As Lou Henkin famously said of sovereignty, "Away with the 'S' word!" 27 However, debates within foreign relations scholarship (such as the status of international law in the United States) turn on the type of outdated notions of federalism 28 that new approaches to federalism persuasively criticize.

Drawing on international law and international relations theory, this Article fills a conceptual gap in the existing federalism literature, which focuses on the two levels of federal and sub-federal governments. This Article adds international governance as the third level, illustrating how international, national, and subnational institutional regimes ${ }^{29} \mathrm{can}$

26 Respectively, see, for example, John O. McGinnis \& Mark L. Movsesian, The World Trade Constitution, 114 HARV. L. REV. 511 (2000) (discussing how international trade law infringes on sovereignty); Joan Fitzpatrick, The International Dimension of U.S. Refugee Law, 15 BERKELEY J. INT'L L. 1 (1997) (recognizing the shortcomings of U.S. conformity with international norms, while also noting the ways international refugee law has penetrated U.S. sovereignty through statutory incorporation of international standards, including, for example, the Refugee Act of 1980, to conform with the 1967 Protocol relating to the Status of Refugees); Anne-Marie Slaughter, Sovereignty and Power in a Networked World Order, 40 STAN. J. INT'L L. 283, 285-95 (2004) (describing the "new sovereignty," a sovereignty separated from classic Westphalian sovereignty, as one which allows for a "transgovernmental network approach to global antitrust regulation"); Anne-Marie Slaughter, Security, Solidarity, and Sovereignty: The Grand Themes of UN Reform, 99 AM. J. INT'L L. 619, 625 (2005) (discussing the evolution of sovereignty as a right to sovereignty as a responsibility, for example, in the context of the international Responsibility to Protect doctrine, which reflects the protection of civilians as a matter of international concern, given that international law has pierced the veil of sovereignty); Ruti G. Teitel, Humanity's Law: Rule of Law for the New Global Politics, 35 CORNELL INT'L L.J. 355, 385 (2002) (noting that contemporary international humanitarian and human rights law "penetrating national sovereignty" is seen as justified intervention).

27 See, e.g., Louis Henkin, The Mythology of Sovereignty, AM. SOC'Y INT'L L. NEWSL., Mar 1993, at 1; Louis Henkin, War and Terrorism: Law or Metaphor, 45 SANTA ClARA L. REV. 817, 818 n.2 (2005) (noting he "was particularly troubled by the invocation of 'state sovereignty' in argument against an international law of human rights"); Louis Henkin, That "S" Word: Sovereignty, and Globalization, and Human Rights, Et Cetera, 68 FORDHAM L. REV. 1, 1 (1999) ("I don't like the "S word." Its birth is illegitimate, and it has not aged well."); Anne-Marie Slaughter \& Catherine Powell, Louis Henkin (1917-2010): The Power of His Ideas Live On, OPINIO JURIS (Oct. 22, 2010), http://opiniojuris.org/2010/10/22/louis-henkin-1917-2010-thepower-of-his-ideas-live-on [https://perma.cc/W9P9-LVZ3] (discussing this insight as a central part of Henkin's legacy).

28 For my own critique of this tendency in the international law and foreign affairs scholarship, see generally Powell, supra note 10.

29 In a sense, this Article builds off of Robert Putnam's classic game-theoretical model recognizing that national-level policymakers face two separate constituencies when making 
catalyze one another to address fundamental political market failures. As today's climate and immigration debates demonstrate, policies developed within (and between) these three levels are often deeply intertwined. Importantly, the direction of influence moves in multiple directions. For example, while today, state and local governments are paving the way in addressing climate change, some national leaders are calling for a "green new deal" 30 -raising the possibility of national leadership on climate policy if these calls can be eventually adopted into federal policy.

To demonstrate the relevance of international law and international relations theory to federalism, I build on the theory of dialogic federalism, which I have elaborated elsewhere. ${ }^{31}$ This Article looks beyond dialogue to explore how international norms inevitably seep in, not only through traditional top-down treaty ratification, but also through "multiple ports of entry" 32 that enable bottom-up and horizontal forms of governance. While in recent years, scholarly analyses of bottom-up governance and popular constitutionalism have

decisions: domestic-level groups and international-level groups. Robert D. Putnam, Diplomacy and Domestic Politics: The Logic of Two-Level Games, 42 INT'L ORG. 427 (1988).

30 Miles Kampf-Lassin, Bernie Sanders and Alexandria Ocasio-Cortez Are Pushing a Bold New Plan to Tackle Climate Change, IN THESE TIMES (Dec. 4, 2018), http://inthesetimes.com/ article/21615/bernie-sanders-alexandria-ocasio-cortez-climate-town-hall-green-new-deal [https://perma.cc/L7ZX-P4ZZ]. Note that since the notion of a green new deal gained prominence with the 2018 midterm election of Alexandra Ocasio-Cortez-largely following the period this author wrote the bulk of the present Article-the green new deal is not a focus here. While the idea of the green new deal is potentially quite important for moving climate policy toward addressing climate justice, the scope of this potential (and how it fits into the questions of federalism posed here) is not yet fully clear to this author.

31 Powell, supra note 10, at 249-50, 253 (adapting critique developed in the habeas corpus context to fit the international human rights law context, based on Robert M. Cover \& $\mathrm{T}$. Alexander Aleinikoff, Dialectical Federalism: Habeas Corpus and the Court, 86 YALE L.J. 1035, 1047 (1977)). In dialogic federalism, intergovernmental relations are a way to embrace, rather than avoid, conflict and indeterminacy. By envisioning a dialogic approach to work through policy differences, dialogic federalism calls for the involvement of numerous stakeholders and multiple levels of government as a way to more democratically and effectively incorporate international law into U.S. law. Id. at 249, 253. See also Robert M. Cover, The Uses of Jurisdictional Redundancy: Interest, Ideology, and Innovation, 22 WM. \& MARY L. REV. 639, 640, 642-43 (1981).

32 This phrase draws inspiration from Judith Resnick's Article on this notion. Judith Resnik, Law's Migration: American Exceptionalism, Silent Dialogues, and Federalism's Multiple Ports of Entry, 115 YALE L.J. 1564 (2006). 
become widespread among constitutional law theorists, 33 in fact, similar ideas of devolution and decentralized authority animate core doctrine in international law as well. ${ }^{34}$

"States' rights" were once regularly invoked by states in the U.S. South to resist racial justice and civil rights. ${ }^{35}$ Today, federalism no longer has a definitive ideological valence. It would be, of course, naïve to say that "states' rights" are no longer used to reject civil rights. But with the diffusion of the rights idea, ${ }^{36}$ today's state and local governments occasionally embrace localism to protect human rights. ${ }^{37}$

33 For classics in this area, see, for example, Michael C. Dorf \& Charles F. Sabel, A Constitution of Democratic Experimentalism, 98 COLUM. L. REV. 267 (1998); LARRY D. KRAMER, The People Themselves: Popular Constitutionalism and Judicial Review (2004); Mark TUSHNET, TAKING THE CONSTITUTION AWAY FROM THE COURTS (1999).

34 Devolution and decentralization are pervasive in international law doctrine, including in notions such as, for example, (1) complementarity in the International Criminal Court statute and (2) subsidiarity in E.U. law. On complementarity, see, for example, The Principle of Complementarity and the Exercise of Universal Jurisdiction for Core International Crimes, F. FOR INT'L CRIM. \& HUMANITARIAN L. (Sept. 4, 2009), https://www.fichl.org/activities/theprinciple-of-complementarity-and-the-exercise-of-universal-jurisdiction-for-core-inter national-crimes [https://perma.cc/QV7N-ZGRU] ("The complementarity principle on which the International Criminal Court (ICC) is based entails that the ICC can only investigate and prosecute core international crimes when national jurisdictions are unable or unwilling to do so genuinely."). On subsidiarity, see Charles F. Sabel \& Jonathan Zeitlin, Learning from Difference: The New Architecture of Experimentalist Governance in the European Union 6 (European Governance Papers, Paper No. C-07-02 May 10, 2007), https://www.researchgate.net/profile/ Jonathan_Zeitlin/publication/28627560_Learning_from_Difference_The_New_Architecture_ of_Experimentalist_Governance_in_the_European_Union/links/54060ec30cf2bba34cle3ccf/ Learning-from-Difference-The-New-Architecture-of-Experimentalist-Governance-in-theEuropean-Union.pdf [https://perma.cc/4DBL-486S] (citing earlier work by E.U. scholar Gráinne de Búrca, and noting, "Subsidiarity in this architecture implies that in writing framework rules the lower-level units should be given sufficient autonomy in implementing the rules to be able to propose changes to them"). See also Levit, supra note 25.

35 See, e.g., Governor George Wallace of Ala., Inaugural Address (Jan. 14, 1963) ("Segregation now, segregation forever").

36 Cf. Louis Henkin, The Rights of MAN TOdAy 22 (1978) (describing how the rights idea became increasingly internationalized and universalized); LOUIS HENKIN, THE AGE OF RIGHTS (1990) (same).

37 For a discussion of an example of localism as a mode of implementing human rights, see, for example, Catherine Powell, Lifting Our Veil of Ignorance: Culture, Constitutionalism, and Women's Human Rights in Post-September 11 America, 57 HASTINGS L.J. 331, 378-83 (2005) (discussing state and local "adoption" of human rights treaties, where the federal government has refused to, for instance on women's human rights). As Gerken notes, rights and federalism are not necessarily at odds with each other, but are "interlocking gears in a disaggregated 
The questions facing courts and other legal decision-makers are who gets to decide these pressing policy questions, and whether and how the country can tolerate a multitude of responses. ${ }^{38}$

Part I outlines the theoretical framework for this Article as well as its limitations. This Part analyzes the two forms of market failure in our national political process: (1) regulatory capture by influential minority economic interests (such as the fossil fuel industry in the climate context), and (2) systematic minority underrepresentation and vulnerability driven by outright hostility (in the immigrant context). Part II examines how-by shifting from a top-down centralized approach to a bottom-up decentralized approach-environmental governance is addressing the first type of market failure (regarding overrepresentation), both from above and below the nation-state. By contrast, Part III identifies how sanctuary jurisdiction policies respond to John Hart Ely's insight about the second type of market failure (underrepresentation of minority rights), though the response here is primarily from below the nation-state, not from above. Part IV presents my conclusions on how federalism and international law would ideally work together to address political market failures, as they currently do in the climate policy context but not the immigration context.

As both case studies suggest, the value of federalism operates not only as an essential lynchpin of our democracy within the elaborate structure of our constitutional law, but also as a mechanism to address entrenched failures in our national politics-whether at the federal or sub-federal level. Where international standards are available to help further address these failures-particularly for issues that are inherently transnational-federalism can also serve a vital function in advancing international law norms, by facilitating internalization of international

democracy." Gerken, supra note 22, at 1713. See also Olatunde C.A. Johnson, The Local Turn; Innovation and Diffusion in Civil Rights Law, 79 L. \& CONTEMP. Probs. 115 (2016) (noting innovative responses by states and localities to inequality, as the prospect of sweeping new federal civil rights measures fades); Heather K. Gerken, Windsor's Mad Genius: The Interlocking Gears of Rights and Structure, 95 B.U. L. REV. 587 (2015).

38 As discussed below, the dilemma is reflected both in the climate change context (with regard to the dispute over the Trump administration's plan to withdraw California's waiver for more stringent automobile emissions standards) and in the immigration context (as reflected in suits and counter suits between states and the federal government over sanctuary policies). See infra Parts II \&III, respectively. 
norms locally and by even assisting in fulfillment of these norms on the global stage. ${ }^{39}$ Again, while the climate policy case study demonstrates the important ways that federalism and international legal norms can support each other, this is less so in the case of immigration policy, where international protection is less robust. Therefore, the federalism debate in immigration turns primarily on domestic allocation of power considerations-and thus on the issue of noncooperation with the federal government ${ }^{40}$-as formal international human rights (and domestic constitutional rights) legal protections of these individuals are quite weak. As such, these two case studies set up an interesting contrast at the intersection of federalism, constitutionalism, and internationalism.

\section{Adapting Ely's Notion of Correcting Political Market Failure}

This Part analyzes two forms of political market failures to explain-and defend-the turn to lawmaking from below (and above, where possible) the nation-state to challenge:41 (1) minority

39 While my earlier work examined how federalism can assist with internationalization of international norms, this Article goes further in theorizing how the interaction of federalism and international standards addresses political failures.

40 In his canonical article on sanctuary policies, Huyen Pham frames these policies in terms of noncooperation. Huyen Pham, The Constitutional Right Not to Cooperate? Local Sovereignty and the Federal Immigration Power, 74 U. CIN. L. REV. 1373 (2006).

41 Note that while this account of political market failures draws inspiration from and adapts the theories of judicial review identified by John Hart Ely and Niels Petersen (discussed supra in the Introduction), several other scholars have extended the market analogy to the political process. Notably, see Samuel Issacharoff \& Richard H. Pildes, Politics as Markets: Partisan Lockups of the Democratic Process, 50 STAN. L. REV. 643, 646 (1998) (warning that "[i]n political markets, anticompetitive entities alter the rules of engagement to protect established powers from the risk of successful challenge" and noting that " $[t]$ his market analogy may be pushed one step further if we view elected officials and dominant parties as a managerial class, imperfectly accountable through periodic review to a diffuse body of equity holders known as the electorate."); Michael Pal, Breakdowns in the Democratic Process and the Law of Canadian Democracy, 57 MCGILL L.J. 299, 304-05 (2011) (noting that a court's role within a theory of political competition is one which "[ensures] that political insiders do not use their existing political authority to 'chok[e] off the channels of political change," and that courts function as "antitrust regulators" in order to ensure political markets stay competitive); and Yen-Tu Su, Retracing Political Antitrust: A Genealogy and Its Lessons, 27 J.L. \& PoL. 1, 8-9 (2011) (criticizing Ely's approach for failing to capture the whole picture and discussing political antitrust approach as another way to describe the political market approach). 
underrepresentation resulting from being systematically locked out of political power (as with immigrants), and (2) regulatory capture by powerful minority economic interests (as with the deregulation and rollback of climate policy). While the first type of political market failure results when minorities are systematically underrepresented, in the second form of market failure, the problem is reversed, where influential minorities dominate the political process through regulatory capture and externalize the negative effects of policy decisions that benefit them. Because the first type of market failure is the one scholars most associate with John Hart Ely's classic theory, I turn to that first, before turning to the second form of failure. Subsequent Sections in this Part refine the theoretical framework for the Article and point to limitations for the analysis.

\section{A. Immigrants' Rights: The Problem of Minority Underrepresentation}

I start with the minority underrepresentation problem, because this is the more familiar dilemma for both constitutional and international law reflected: (1) in constitutional law's protection of "discrete and insular minorities" (as the Supreme Court identified in Carolene Products), as well as (2) in international law's bill of rights. ${ }^{42}$ Noncitizen

42 In constitutional law, see, e.g., United States v. Carolene Prods. Co., 304 U.S. 144, 152 n.4 (1938). In international law, see, e.g., International Covenant on Civil and Political Rights art. 2, Dec. 19, 1966, 999 U.N.T.S. 171 [hereinafter ICCPR]; id. art. 26. See also U.N. Charter art. 1, g 3; International Convention on the Elimination of All Forms of Racial Discrimination, Mar. 7, 1966, 660 U.N.T.S. 195.

The treatment of foreign nationals as "minorities" (including religious minorities and prisoners of war) was among the earliest concerns in international human rights law and continues to be at the center of efforts to prevent international conflict and warfare. Protections for foreign nationals who are religious minorities (in the foreign country) came to fruition in the twentieth century inter-war period, when Central and Eastern European countries adopted minority rights regimes for religious and linguistic minorities in the aftermath of World War I. For example, see the famous case Minority Schools in Albania, 1935 P.C.I.J. (ser. A/B) No. 64 (Apr. 6) (advisory opinion) (as the precursor to the International Court of Justice, the Permanent Court of International Justice highlighted the importance of protections in the Minorities Treaties for religious, linguistic, and racial minorities, such as the Christian minority of Greek origin in predominantly Muslim Albania). As for protections of foreign nationals as prisoners of war, see THEODOR MERON, BLOODY CONSTRAINT: WAR AND CHIVALRY IN SHAKESPEARE (1998) (tracing humanitarian norms back to at least Shakespearean times, as reflected in Shakespeare's plays revealing norms of the times); Theodor Meron, The 
immigrants are quintessential outsiders. ${ }^{43}$ Ely recognizes that a root cause of vulnerability for noncitizens is their exclusion from the formal political process-such that "any representation they receive will be exclusively 'virtual."' 44 As David Cole notes:

As a group that is subject to government regulation but denied a vote, aliens are without a meaningful voice in the political bargains struck by our representative system. Members of Congress have little reason to concern themselves with the rights and interests of those who cannot vote. Thus, as John Hart Ely has argued, aliens' interests will almost by definition be undercounted in the political process; they are a "relatively easy case" of a "discrete and insular minority" deserving of heightened protection. 45

In addition to being disenfranchised politically, noncitizens are largely barred from running for national office. ${ }^{46}$ Further, noncitizens have

Humanization of Humanitarian Law, 94 AM. J. INT'L L. 239 (2000) (reflecting on the evolution of international humanitarian law's treatment of prisoners of war from the Hague Convention to the Geneva Convention and beyond).

43 Further, many Latinx (and other) citizens are sometimes presumed to be undocumented immigrants and are often treated as outsiders on this basis, when, for example, stopped by the police based on their skin color and/or appearance. See, e.g., Jennifer M. Chacón, Producing Liminal Legality, 92 DENV. U. L. REV. 709, 753 (2015) ("citizens who are policed more heavily because they bear the visible markers of race or ethnicity that correlate to other forms of liminal legal status"); Jennifer M. Chacón, Citizenship Matters: Conceptualizing Belonging in an Era of Fragile Inclusions, 52 U.C. DAVIS L. REV. 1, 64 (2018) [hereinafter Chacón, Conceptualizing Belonging] ("formal citizenship does not protect people from discriminatory policing"). It is well-documented that racial profiling is an entrenched problem-posing serious and unconstitutional over- and under-inclusivity challenges-both inside and outside the context of immigration. See, e.g., David A. Harris, "Driving While Black" and All Other Traffic Offenses: The Supreme Court and Pretextual Traffic Stops, 87 J. CRIM. L. \& CRIMINOLOGY 544 (1997); Stefano Bonino, How Discrimination Against Muslims at Airports Actually Hurts the Fight Against Terrorism, WASH. POST (Aug. 26, 2016), https://www.washingtonpost.com/news/ monkey-cage/wp/2016/08/26/how-discrimination-against-muslims-at-airports-actually-hurtsthe-fight-against-terrorism/?utm_term=.5e927210b144 [https://perma.cc/G9AB-SLGP].

44 ELY, supra note 13, at 161-62.

45 David Cole, Enemy Aliens, 54 STAN. L. REV. 953, 981 (2002)

46 Id. at $981 \mathrm{n} .114$ ("Interestingly, while citizenship is a constitutional prerequisite to running for president or Congress, the political branches, it is not a requirement for those who make up the federal judiciary responsible for enforcing constitutional rights."); see also ELY, supra note 13, at 161 ("our legislatures are composed almost entirely of citizens who have always been such"). But see Chacón, Conceptualizing Belonging, supra note 43, at 57-58 
faced considerable prejudice throughout our history and often live in somewhat discrete and unassimilated communities. ${ }^{47}$

The argument made by Ely and Cole is an argument about how the underrepresentation of noncitizens in our political system is classic political market failure. Noncitizens are subject to government regulation, but do not have a meaningful voice or vote in the formulation of its regulation. Of course, social contract theory could be used to justify the exclusion of noncitizens from being able to formally participate in the political process, though behind a Rawlsian veil of ignorance, we are all potential immigrants. ${ }^{48}$ But as I read Ely and Cole, their argument is less about granting a formal voice or vote to undocumented immigrants and more a contention for constitutional rights protection and judicial intervention to vindicate basic rights. ${ }^{49}$ The fact that undocumented immigrants meet the classic criteria of minority status highlights the need for both constitutional rights protection and a heightened standard of review by courts. 50

For the purposes of my analysis regarding federalism, this Article takes the point Ely and Cole make about the importance of horizontal separation of powers, and adapts it to offer new insight about vertical separation of powers. Noncitizens are underrepresented in our national political process, even as they are subject to federal authority. ${ }^{51}$

Of course, immigration law is inherent in national sovereignty, 52 and one might argue that immigrants who are out-of-status ${ }^{53}$ are not

(discussing ways immigrants are active politically beyond the formal ability to vote or run for office).

47 Cole, supra note 45 , at 981 n. 113.

48 JOHN RAWLS, A THEORY OF JUSTICE (1999).

49 See, e.g., Cole, supra note 45, at 981 ("[T]he fact that the Constitution denies aliens the right to vote makes it that much more essential that the basic rights reflected in the Bill of Rights be extended to aliens in our midst.").

50 Id. at 981; ELY, supra note 13, at 103.

51 On this point, note Justice Brennan's dissent from (and criticism of) the idea advocated by the majority of the Court that "although foreign nationals must abide by our laws even when in their own countries, our Government need not abide by the Fourth Amendment when it investigates them for violations of our laws." United States v. Verdugo-Urquidez, 494 U.S. 259, 279 (1990) (Brennan, J., dissenting). Furthermore, Brennan argued that the Fourth Amendment focuses "on what the Government can and cannot do, and how it may act, not on against whom these actions may be taken." Id. at 288 (Brennan, J., dissenting).

52 Immigration is understood as bound up in the federal government's control over matters related to sovereignty. See, e.g., Jennifer Gordon, Immigration as Commerce: A New Look at the 
entitled to the protection afforded those who are in-status. At the same time, there are broader questions about how federal immigration laws are conceived of and enforced, which are beyond the scope of this Article. ${ }^{54}$ But once immigrants are in the United States and making substantial contributions to the economy and the fabric of various communities, other questions arise concerning their rights and status. 55

Federal Immigration Power and the Constitution, 93 IND. L.J. 653, 654 (2018) ("For well over a century, federal courts have often relied on the theory that the immigration authority is rooted in the Constitution's grant to the federal government of control over matters related to sovereignty and foreign affairs.").

53 I am using the terms "out-of-status" and "undocumented" immigrants to describe immigrants who were either unauthorized to enter the United States or stay beyond their authorization. I prefer the "out-of-status" and "undocumented" terminology, as there are a variety of reasons immigrants are in the country without proper documentation. Many immigrants try to enter legally but end up with unscrupulous lawyers who fail to take the necessary steps to assist immigrants normalize their status.

More fundamentally, U.S. involvement in many parts of world undercuts the argument that the United States bears no responsibility and obligation to immigrants seeking to come to the United States. Garrett Hardin famously uses the metaphor of "lifeboat ethics" to assert that the carrying capacity of each country depends upon its ability to help immigrants from poor countries without causing great detriment to those already in the metaphorical boat. See Garrett Hardin, Lifeboat Ethics: The Case Against Helping the Poor, GARRETT HARDIN SOC'Y (Sept. 1974), http://www.garretthardinsociety.org/articles/art_lifeboat_ethics_case_against_helping poor.html_https://perma.cc/J3B5-MBSN]. However, U.S. responsibility for underdevelopment in other countries might change the calculus in Hardin's famous tragedy of the commons framework. Those in the U.S. lifeboat may have helped create the leaky conditions in the other boat. For a discussion of the negative impacts of U.S.-led economic and trade policies in Latin America, see Chantal Thomas, Disorderly Borders: How International LaW SHAPES IRREGULAR MigRATION 71 (forthcoming under contract with Oxford Univ. Press) (on file with author) (chapter 2.1) (exploring the idea that the United States has particular obligations to immigrants from Latin America, given the impact of structural adjustment and trade liberalization (often referred to the Washington Consensus) in countries throughout Central and South America). For a discussion of the negative impacts of U.S. and European colonialism and imperialism in less powerful parts of the world, see ANTONY ANGHIE, IMPERIALISM, SOVEREIGNTy AND THE MAKING OF InTERnational LAW (2005); Tony Anghie \& Wayne McCormack, The Rights of Aliens: Legal Regimes and Historical Perspectives, in MIGRATION IN THE 21ST CENTURY: Rights, OUtCOMES AND POLICY 23 (Thomas N. Maloney \& Kim Korineck eds., 2011).

54 Note that other scholars are involved in exploring important questions of postnational membership, such as in the European Union context. See, e.g., CHRISTIAN JOPPKE, CiTIZENSHIP AND IMMIGRATION (2010).

55 See, e.g., Chacón, Conceptualizing Belonging, supra note 43; see also Plyler v. Doe, 457 U.S. 202 (1982) (recognizing that undocumented children could not be denied access to public 
Through sanctuary policies, state, county, and local governments assert an interest in building trust with immigrant communities to advance pragmatic law enforcement and local sovereignty objectives, as well as to promote altruistic values regarding building diverse, inclusive communities, and vindicating human dignity. The aim of respecting the rights of individuals simply by virtue of each person's humanity is not a foreign idea. In fact, it was a concept established as a fundamental political and constitutional ideal at the founding of the United States, ${ }^{56}$ and was later promoted internationally by the United States-across Republican and Democratic administrations-in the aftermath of the Nazi Holocaust, through the Cold War, and up through today. ${ }^{57}$ In short, whether based on considerations of altruism or pragmatism, by refusing cooperation with the federal government's restrictive immigration policies, sanctuary jurisdictions address the failure in our national politics of subjecting noncitizens to increasingly draconian federal government regulations, particularly where noncitizens do not have an effective voice or vote in the formulation of these regulations. ${ }^{58}$

schools, on equal protection grounds, as to deny them access would be to create a permanent underclass living in our midst).

56 The Declaration of IndePendence (U.S. 1776) (declaring that "all men are created equal" and "are endowed by their Creator with certain unalienable rights"). The American Declaration and U.S. Constitution-overlaid with social contract theory-eventually secularized the idea of rights, which started out as a natural law idea based in religion. See HENKIN, THE RIGHTS OF MAN TODAY, supra note 36, at 22.

57 See, e.g., Mary Ann Glendon, A World Made New: Eleanor Roosevelt and the Universal Declaration of Human Rights (2001); Henkin, The Rights of MAN TODAY, supra note 36; Michelle Singer, Ford's Grades for Carter, Reagan, Nixon, CBS NEWs (Jan. 12, 2007, 10:38 PM), https://www.cbsnews.com/news/fords-grades-for-carter-reagan-nixon [https://perma.cc/9T8Y-PLFJ] (Gerald Ford contended his negotiation of the Helsinki Accord on human rights did more to win the Cold War than Reagan's Pentagon buildup); Felicia Schwartz, In Cuba Policy Shift, Trump Stresses Human Rights, Mutes Concerns Elsewhere, WALL STREET J. (June 17, 2017, 7:00 AM), https://www.wsj.com/articles/in-cuba-policy-shift-trumpstresses-human-rights-mutes-concerns-elsewhere-1497697200 [https://perma.cc/6GJ9-AZ4G]; Kevin Liptak \& Dan Merica, For Trump, A Selective Focus on Human Rights, CNN: Pol. (June 17, 2017, 8:32 AM), https://www.cnn.com/2017/06/17/politics/trump-human-rightscuba/index.html [https://perma.cc/UG8Y-TJW5].

58 Note there is a debate on the extent to which sanctuary policy is or is not about "resistance" and obstruction. Compare Jason A. Cade, Sanctuaries as Equitable Delegation in an Era of Mass Immigration Enforcement, 113 NW. U. L. REV. 433, 433 (2018) (stating that rather than view sanctuary "as obstructions to the operation of federal immigration law[,]" the better view is that "the sanctuary movement comports with, rather than fights against, dominant new 


\section{B. Climate Policy: The Problem of Regulatory Capture by Influential Economic Minorities}

As for the second form of political market failure, climate policy reflects regulatory capture by powerful minority economic interests, particularly the fossil fuel industry. Some leaders within the industry have successfully pushed the Trump administration to reverse federal climate change policies that these leaders claim threaten the economic future of coal and other fossil fuels. ${ }^{59}$ While there is a movement away from fossil fuels to cleaner sources of energy on purely economic grounds (to compete with China, Europe, and other parts of the world that are making strides in clean energy, as the economy of tomorrow, rather than the economy of the last century), ${ }^{60}$ many fossil fuel companies are resistant to this transition and efforts to be regulated.

The problem of regulatory capture by powerful minority economic interests does not necessarily fit squarely within either the John Hart Ely or Carolene Products frameworks. However, Bruce Ackerman notes the "discrete and insular minority" framing could actually be interpreted as over-inclusive (in that small, but powerful economic interests, could, in fact, be swept within the notion of "discrete and insular," but clearly did

themes in federal immigration law ... [by] erect[ing] front-line equitable screens, promot[ing] procedural fairness, and act[ing] as last-resort circuit breakers in the administration of federal deportation law."), with Rose Cuison Villazor \& Pratheepan Gulasekaram, Sanctuary Networks, 103 MinN. L. REV. 1209 (2019).

59 See, e.g., Jeff Brady, Fossil Fuel Industry Pushes for Clean Power Plant Replacement, NPR (Dec. 21, 2017, 4:55 PM), https://www.npr.org/2017/12/21/572699233/fossil-fuel-industrypush-for-clean-power-plan-replacement [https://perma.cc/DCV6-TMNN]; Jared Keller, Oil and Gas Ties Run Deep in the Trump Administration, PAC. STANDARD (Jan. 5, 2018), https:// psmag.com/environment/oil-and-gas-ties-run-deep-in-trump-administration [https:// perma.cc/AZS2-AXPY] (discussing how policy and political connections affect industry).

60 Frank Jossi, Sustainable: Presenting the Business Case for Clean Energy, FIN. \& CoM. (June 6, 2017, 7:02 AM), https://finance-commerce.com/2017/06/sustainable-presenting-thebusiness-case-for-clean-energy [https://perma.cc/KG3X-3AMJ]; RENEWABLE CHOICE ENERGY, The Economic Case for Renewable Energy: Why Companies are Choosing Power PURCHASE AGREEMENTS (2017), http://www.renewablechoice.com/wp-content/uploads/2017/ 01/Economic-Case-for-Renewable-Energy-White-Paper-2017.pdf [https://perma.cc/9TY4XXWG]; Daniel Kammen, A Letter to Mr. Trump: The Economic Case for Energy, Equity and Climate Leadership, U.C. BERKELEY BLOG: ENV'T (Nov. 15, 2016), http://blogs.berkeley.edu/ 2016/11/15/a-letter-to-mr-trump-the-economic-case-for-energy-equity-and-climate-leadership [https://perma.cc/G2UT-TQ6F]. 
not qualify for heightened judicial scrutiny in the famous footnote) and under-inclusive (in that it was unclear that women, for example, fit squarely in the original conception). ${ }^{61}$

For this reason, Ackerman critiques the "discrete and insular minority" notion, arguing, "Other things being equal, 'discreteness and insularity' will normally be a source of enormous bargaining advantage, not disadvantage, for a group engaged in pluralist American politics." 62

While the Supreme Court has moved from the "discrete and insular minority" framework to other criteria, 63 it is nonetheless useful to flip this framework on its head, per Ackerman's intuition, at least as a conceptual matter (if not a doctrinal matter) to consider how powerful minority economic interests have an unfair advantage (as opposed to an unfair disadvantage, the way other minority groups have).

Another way to think about regulatory capture by powerful minority economic elites as a form of political market failure is through the lens of Reynolds $v$. Sims. 64 According to that landmark case, the normative baseline for fairness in the political process in our democracy is "one person, one vote." ${ }_{55}$ However, money and corporate influence distort this baseline, particularly in the aftermath of Citizens United $v$. Federal Electric Commission, which protected political spending as free speech.66 Disproportionate political influence-grounded in economic power that helps secure political access through campaign contributions, etc.-is not only in tension with the "one person, one vote" notion, but also leads to informational asymmetries (as discussed further infra). As Alexander Meiklejohn notes, speech contributes to the

61 Bruce A. Ackerman, Beyond Carolene Products, 98 HARv. L. Rev. 713 (1985).

62 Id. at 723-24 (adding "the concerns that underlie Carolene should lead judges to protect groups that possess the opposite characteristics from the ones Carolene emphasizes-groups that are 'anonymous and diffuse' rather than 'discrete and insular.'”).

63 Due to conceptual problems with applying the "discrete and insular minority" framework, the Supreme Court has moved toward criteria such as immutability, historical disadvantage, and others. See, e.g., Craig v. Boren, 429 U.S. 190 (1976); Frontiero v. Richardson, 411 U.S. 677 (1973).

64377 U.S. 533 (1964).

$65 \mathrm{Id}$. at 558.

66558 U.S. 310 (2010) (holding that political spending is protected speech under the First Amendment). 
democratic process, ${ }^{67}$ yet there must be a level playing ground. Particularly in an era of digital media, powerful actors are even more likely to wield greater power over speech and political influence. ${ }^{68}$

Despite overwhelming scientific evidence, 69 President Trump tweeted, "The concept of global warming was created by and for the Chinese in order to make U.S. manufacturing non-competitive." 70 No evidence to support this claim has been produced, yet when asked about this statement, administration officials have largely evaded defending the core of the claim, suggesting instead that the problem the President was trying to highlight was a more general concern about competitiveness. ${ }^{71}$

At the November 2017 two-year anniversary meeting of the 2015 Paris climate change agreement, the Trump administration's only public meeting on climate change focused on the future of the coal sector. ${ }^{72}$ Whereas deregulation and support for a more open economy ${ }^{73}$ is a credible "neutral principle" 74 - to use Herbert Weschler's terminologyPresident Trump has spearheaded efforts to end regulations on climate policy that supports the fossil fuel sector, while at the same time going in a somewhat inconsistent direction as regards deregulation in the

67 Alexander Meiklejohn, Free Speech and Its Relation to Self-Government (2001).

68 See On the Media: Is the 1st Amendment Obsolete?, N.Y. PUB. RadiO (Sept. 7, 2018) (downloaded using iTunes) (interview with Timothy $\mathrm{Wu}$, discussing ideas that appear in Timothy Wu, Is the First Amendment Obsolete?, in THE Free SPEeCH CENTURY (Lee C. Bollinger \& Geoffrey R. Stone eds., 2018)).

69 For discussion of the scientific research, see discussion infra Part II.

70 Tom DiChristopher, Climate Change Deniers Are Plotting Trump's Path to the Holy Grail of Deregulation, CNBC (Nov. 22, 2017, 11:15 AM), https://www.cnbc.com/2017/11/22/climatechange-deniers-plot-trumps-path-to-deregulation.html [https://perma.cc/GK2H-8ZU4].

71 Umair Irfan, The Trump Administration Went to the UN Climate Talks to Promote Coal, Vox (Nov. 14, 2017, 9:20 AM), https://www.vox.com/energy-and-environment/2017/11/14/ 16634480/us-coal-nuclear-climate-change-cop23-protest [https://perma.cc/4NG2-VVPA] (noting that when a Chinese reporter asked a Trump advisor about Trump's "Chinese hoax" tweet, the response was that the point of tweet was mostly about competitiveness).

72 Id.

73 Tracking Deregulation in the Trump Era, BROOKINGS (May 16, 2019), https:// www.brookings.edu/interactives/tracking-deregulation-in-the-trump-era [https://perma.cc/ PVH8-L4BA].

74 Herbert Wechsler, Toward Neutral Principles of Constitutional Law, 73 HARV. L. REV. 1 (1959). 
context of steel. For example, in March 2018, Trump announced tariffs on steel imports, designed to protect the steel sector. ${ }^{75}$ Such inconsistency in following the principle of deregulation is telling. The President's policy choices seem, instead, consistent in his commitment to protecting at least certain sectors of the economy-fossil fuels and steel-that are geographically concentrated in white, working class, and/or more conservative parts of the country that support him (such as Texas and the rust belt). ${ }^{76}$

This is a classic example of how a policy that is "inconsistent or incoherent in pursuing certain goals" (in this case a claimed neutral principle of deregulation that Trump frequently asserts as a primary goal of his administration) "can [] be an indication that [the policy] also pursued secondary goals, such as particularistic interests" (in this case, the advancement of economic interests for the coal and steel sectors, respectively). 77 The uses of such proxies are indicative of regulatory

75 Section 232 Tariffs on Aluminum and Steel, U. S CUSTOMS \& BORDER PROTECTION, https:// www.cbp.gov/trade/programs-administration/entry-summary/232-tariffs-aluminum-and-steel [https://perma.cc/PLX6-VJ75] (last updated May 29, 2019); Scott Horsley, Trump Formally Orders Tariffs on Steel, Aluminum Imports, NPR (Mar. 8, 2018, 5:00 AM), https://www.npr.org/ 2018/03/08/591744195/trump-expected-to-formally-order-tariffs-on-steel-aluminum-imports [https://perma.cc/HPF3-ZHKY].

76 As regards white working class voters with ties to the steel industry, see, e.g., Asma Khalid, Steel Country Democrats Who Backed Trump Weigh Party Loyalty in 2018, NPR (Mar. 9, 2018, 5:01 AM), https://www.npr.org/2018/03/09/591014346/steel-country-democrats-whobacked-trump-weigh-party-loyalty-in-2018 [https://perma.cc/QJ4R-YJ7C]. As regards white working class voters with possible ties to the coal sector, see, e.g., Joshua Zeitz, Does the White Working Class Really Vote Against Its Own Interests?, Politico (Dec. 31, 2017), https:// www.politico.com/magazine/story/2017/12/31/trump-white-working-class-history-216200 [https://perma.cc/8QLC-BB3S].

77 Petersen, supra note 14, at 28; see also Niels Petersen, Legislative Inconsistency and the "Smoking Out" of Illicit Motives, 64 AM. J. CoMP. L. 121, 140 (2016) (discussing how, as an example of political market failure, a legislative majority may be captured by strong interest groups and have incentives to draft private-regarding legislation). While applied inconsistently, the Trump administration has made deregulation a primary policy objective. See, e.g., Fact Sheets: President Donald J. Trump Is Delivering on Deregulation, WHITE HousE (Dec. 14, 2017), https://www.whitehouse.gov/briefings-statements/president-donald-j-trump-deliveringderegulation [https://perma.cc/B3MU-LE6L]; Alan Levin \& Ari Natter, Trump Stretches Meaning of Deregulation in Touting Achievements, BLOOMBERG: POL. (Dec. 29, 2017, 4:00 AM), https://www.bloomberg.com/news/articles/2017-12-29/trump-stretches-meaning-of-

deregulation-in-touting-achievements; Laurent Belsie, Trump's Deregulation Drive Is Epic in Scale and Scope. And Yet..., Christian SCI. MONiTOR (Jan. 5, 2018), https://www.csmonitor.com/ Business/2018/0105/Trump-s-deregulation-drive-is-epic-in-scale-and-scope.-And-yet [https:// 
capture, where the decision-maker offers a proxy as a justification when another basis is the true basis for the policy. 78

The push by certain firms within the fossil fuel industry to oppose climate policy represents a particularly egregious political market failure, given the outsized influence of powerful economic minorities. It signals that those with power are able to externalize the negative effects of policy decisions that benefit them at the expense of the rest of us. Fossil fuel companies can benefit from gutting climate policies (at least in the short term, by pushing off the inevitable economic forces that serve to replace fossil fuels with clean energy), while the rest of us pay the price of the negative effects of climate change. ${ }^{79}$ Plus, the fossil fuel industry's success in lobbying the Trump administration 80 to eviscerate

perma.cc/349P-QEW2]; Nicholas W. Zeppos \& Philip A. Wallach, Tracking Deregulation in the Trump Era, BROOKINGS (Dec. 5, 2017), https://www.brookings.edu/blog/fixgov/2017/12/05/ tracking-deregulation-in-the-trump-era [https://perma.cc/325W-TZ99].

78 Petersen, supra note 14 , at 28.

79 For discussion of the negative effects of climate change, see infra Part II.

80 Furthermore, despite Trump's promise to "drain the swamp," several lobbyists who represented fossil fuel companies are now in senior positions in the Trump administration, including Environmental Protection Agency (EPA) Administrator Andrew Wheeler. See, e.g., Coral Davenport, Trump Administration Wants to Make It Easier to Release Methane Gas into Air, N.Y. TiMES (Sept. 10, 2018), https://www.nytimes.com/2018/09/10/climate/methaneemissions-epa.html?action=click\&module=Top\%20Stories\&pgtype=Homepage [https:// perma.cc/V93X-ZBHJ] (describing Wheeler as “a former coal lobbyist”); Lisa Friedman \& Brad Plumer, E.P.A. Drafts Rule on Coal Plants to Replace Clean Power Plan, N.Y. Times (July 5, 2018), https://www.nytimes.com/2018/07/05/climate/clean-power-plan-replacement.html [https://perma.cc/L369-4NVP] (explaining that before joining the EPA, Wheeler worked as a lobbyist for Robert E. Murray, "a mining executive and a longtime Trump donor"); Lisa Friedman, Andrew Wheeler, New E.P.A. Chief, Details His Energy Lobbying Past, N.Y. Times (Aug. 1, 2018), https://www.nytimes.com/2018/08/01/climate/andrew-wheeler-epalobbying.html [https://perma.cc/BBM7-A87Z] (reporting that Wheeler is serving under an ethical cloud, having not reported related prior lobbying efforts within the two-year ban with sufficient detail). See also Eric Lipton, E.P.A. Rule Change Could Let Dirtiest Coal Plants Keep Running (and Stay Dirty), N.Y. Times (Aug. 24, 2018), https://www.nytimes.com/2018/08/24/ climate/epa-coal-power-scrubbers.html [https://perma.cc/VW8H-VVG8] [hereinafter Lipton, Dirtiest Coal] (explaining that the decision to gut the Obama-era Clean Power Plan "was advocated by William L. Wehrum, a former power-plant industry lawyer who is now in charge of air pollution policy at the E.P.A. and had unsuccessfully sought to make a similar change during the Bush administration, when he also worked at the agency."); Eric Lipton, As Trump Dismantles Clean Air Rules, An Industry Lawyer Delivers for Ex-Clients, N.Y. Times (Aug. 19, 2018), https://www.nytimes.com/2018/08/19/us/politics/epa-coal-emissions-standards-williamwehrum.html [https://perma.cc/ANZ5-XD7X] (reporting "As a corporate lawyer, William L. Wehrum worked for the better part of a decade to weaken air pollution rules by fighting the 
climate policies has effects that will be even more widely felt, given both the broader territorial and temporal impacts. ${ }^{81}$ Territorial external effects of curbing climate policy include the fact that the cost will be borne by people globally outside the United States-so by those who are "not part of the political community making the decision." 82 Temporal external effects of climate change include the fact the cost of resisting responsible climate policy now will be borne by future generations. ${ }^{83}$

\section{Immigration and Climate Policies: Informational Asymmetries and Markets Failures}

Just as economists describe externalization of costs as indicative of market failure, so too they note that information asymmetries are another key symptom of such failures. ${ }^{84}$ Scholars also view race and other forms of impermissible discrimination as economic and political market failures. 85 In the climate and immigration contexts, proxies, coded-language, and dog whistles are used in ways that appeal to particular parts of the electorate, while stigmatizing others.

Environmental Protection Agency in court on behalf of chemical manufacturers, refineries, oil drillers and coal-burning power plants. Now, Mr. Wehrum is about to deliver one of the biggest victories yet for his industry clients [the rollback of the Clean Power Plan] - this time from inside the Trump administration as the government's top air pollution official.").

81 Petersen, supra note 14 , at 31.

82 Id. at 31.

83 As Petersen notes:

Many of the voters who today decide about the composition of the government may then not be alive anymore. At the same time, citizens who will feel the effect of environmental measures that are taken (or not taken) in 20 or 30 years often do not yet have a vote or might even not yet be born.

Id. at 32 .

84 Alex Bowen, Simon Dietz \& Naomi Hicks, Why Do Economists Describe Climate Change as a 'Market Failure'?, GUARDIAN (May 21, 2012, 10:24 AM), https://www.theguardian.com/ environment/2012/may/21/economists-climate-change-market-failure [https://perma.cc/ GUZ5-2V8Y] (making the point that economists describe externalities and lack of information as market failures).

85 Ian Ayres, Market Power and Inequality: A Competitive Conduct Standard for Assessing When Disparate Impacts Are Unjustified, 95 CALIF. L. REV. 669 (2007) (explaining ways in which racial disparity and market failure often come hand in hand). 
Typically, when the government abuses its power or is incompetent, citizens have the right to exit or replace elected representatives in elections. 86 However, information asymmetries undermine the ability of citizens to punish lawmakers-because it is more difficult to vote based on accurate information-thereby weakening accountability and the operation of the political market. The fact that former fossil fuel lobbyists are in charge of making environmental policy (in some cases without adequately disclosing their past lobbying practices) distorts the truth and the basis for policy. ${ }^{87}$

To make matters worse, efforts by the press to unmask these dynamics, create transparency, and promote accountability have been regularly attacked as "fake news." 88 In fact, several of the democratic institutions in our society that are essential to the functioning of political markets (by facilitating speech, revealing information, and curbing abuse) have been under attack. The truth is obscured to advance powerful economic interests; 89 science is questioned;90 climate change research is defunded, under attack, and obscured; ${ }^{91}$ the authority of

86 See generally HiRSCHMAN, supra note 19.

87 See sources cited supra note 80.

88 See RonNell Andersen Jones \& Lisa Grow Sun, Enemy Construction and the Press, 49 ARIZ. ST. L.J. 1301 (2017) (discussing how President Trump's attack on the press as "the enemy" risks triggering the type of exceptionalism that has been used in the past to justify compromise of ordinarily recognized liberties).

89 Lili Levi, The Weaponized Lawsuit Against the Media: Litigation Funding as a New Threat to Journalism, 66 AM. U. L. REV. 761 (2017) (describing a new front in the current war against the media-one in which billionaire private actors clandestinely fund other people's lawsuits in an attempt to censor press entities).

90 DiChristopher, supra note 70.

91 On the hollowing out of funding for research, see Randy Showstack, Climate Research Funding Still Under Threat, Report Warns, EOS (June 21, 2018), https://eos.org/articles/climateresearch-funding-still-under-threat-report-warns [https://perma.cc/WZ3V-SSE2] (warning that although congressional action reversed some of the Trump administration cuts to climate change research funding in 2018, political appointees have "broad discretion to reprogram funding away from climate change"); Natalie Meade, Trump's Cuts in Climate-Change Research Spark a Global Scramble for Funds, NEw YORKER (July 7, 2018) https://www.newyorker.com/ news/news-desk/trumps-cuts-in-climate-change-research-spark-a-global-scramble-for-funds [https://perma.cc/VQ23-LQLZ] (noting that Trump's 2019 budget plan cuts roughly $\$ 460$ million on initiatives related to the environment). On research being attacked or obscured, see Lisa Friedman, Cost of New E.P.A. Coal Rules: Up to 1,400 More Deaths a Year, N.Y. TIMES (Aug. 21, 2018), https://www.nytimes.com/2018/08/21/climate/epa-coal-pollution-deaths.html? emc=edit_na_20180821\&nl=breaking-news\&nlid=17436275ing-news\&ref=cta [https:// 
federal judges is criticized;92 political opponents are threatened with imprisonment; 93 and "alternative facts" are promoted over actual facts. 94

\section{Federalism and Transnationalism as Correctives to Political Market Failure}

While federal law can be shaped from below and above, the direction of influence can run in multiple directions. ${ }^{95}$ But regardless of any particular substantive outcome, the objective of domestic separation of powers helps ensure competition, checks and balances, and

perma.cc/K6W7-R56J] (explaining that as the EPA "works to roll back [the Clean Power Plan] regulations on industry, it has also taken steps to sharply restrict the way it uses data to assess its own proposals"); Coral Davenport, Trump Administration Unveils Its Plan to Relax Car Pollution Rules, N.Y. TIMES (Aug. 2, 2018), https://www.nytimes.com/2018/08/02/climate/ trump-auto-emissions-california.html [https://perma.cc/5CHT-SEMY] (while the Transportation Department's acting administrator for the National Highway Traffic Safety Administration, Heidi King, claimed that the Trump administration's rollback of stricter federal auto emissions standards "could save up to a thousand lives annually by reducing these barriers that prevent consumers from getting into newer, safer cars ... [b] ehind the scenes, Mr. Wheeler and [E.P.A. Administrator for Air and Radiation] Mr. Wehrum have sought to distance themselves from the auto-fatality analysis put forth by Ms. King, out of concern that the numbers might be susceptible to legal challenge.").

92 Karey Van Hall, Trump's Attack on Federal Judge Could Backfire, POLITICO (Feb. 4, 2017, 1:41 PM), https://www.politico.com/story/2017/02/trump-judge-attack-backfire-234649 [https://perma.cc/XRM3-UMZA] (noting President Trump's tweet decrying the opinion by the Republican-appointed District Court Judge James Robart who enjoined the President's Executive Order suspending foreign travelers from majority Muslim countries, which Trump referred to as " $t]$ he opinion of this so-called judge, which essentially takes law-enforcement away from our country, is ridiculous and will be overturned!" and warning that "death \& destruction" could result if the President is not allowed to restrict immigration).

93 Gregory Krieg, Trump Threatens to Jail Clinton If He Wins Election, CNN: POL. (Oct. 10, 2016, 11:30 AM), https://www.cnn.com/2016/10/09/politics/eric-holder-nixon-trumppresidential-debate/index.html; Meghan Keneally \& Conor Finnegan, Trump Goes After Former Clinton Aide Huma Abedin in Tweet, ABC News (Jan. 3, 2018, 10:51 AM), http:// abcnews.go.com/Politics/trump-clinton-aide-huma-abedin-tweet/story?id=52095019 [https:// perma.cc/QF39-XNSZ] (noting Trump tweeted, “Crooked Hillary Clinton's top aid [sic], Huma Abedin, has been accused of disregarding basic security protocols. She put Classified Passwords into the hands of foreign agents ... Jail! Deep State Justice Dept must finally act").

94 NBC News, Kellyanne Conway: Press Secretary Sean Spicer Gave 'Alternative Facts', YOUTUBE (Jan. 22, 2017), https://www.youtube.com/watch?v=VSrEEDQgFc8.

95 As Gerken notes, at all levels, regulatory regimes "sometimes lean[] on one another and sometimes deliberately jostl[e] each other." Gerken, supra note 22, at 1722-23 (speaking domestically and internally about the two levels of federalism). 
accountability. Under the two leading theories of democracy and separation of powers-competitive democracy and deliberative democracy 96 -federalism is viewed as an important check to address political market failures.

Both immigration and environmental law have long been viewed as falling within federal authority. ${ }^{97}$ At the same time, courts have recognized that state and local governments can play important roles in setting boundaries on the federal government's immigration enforcement authority 98 and in prompting the federal government to affirmatively act in the climate context. ${ }^{99}$

96 For further discussion of these two theories, see PETERSEN, supra note 14, at 16-17. For a discussion of competitive democracy, see IAN SHAPIRO, THE STATE OF DEMOCRATIC THEORY (2003). For further discussion of deliberative democracy, see JÜRGEN HABERMAS, BETWEEN FACTS AND NORMS 287-328 (1996); JAMES S. FishKIN, DEMOCRACY AND DELIBERATION: NEW Directions For Democratic Reform (1991); Amy Gutman \& Dennis Thompson, DEMOCRACY AND DISAGREEMENT (1996); Dorf \& Sabel, supra note 33.

97 The Supreme Court has upheld the federal government authority in regulating the environment based on the role of the national government as a sovereign nation involved in negotiating the global commons with other nations. Missouri v. Holland, 252 U.S. 416 (1920) (rejecting Tenth Amendment challenge to the Migratory Bird Treaty Act of 1918, on the grounds that the federal government's implementation of the treaty at issue was constitutional, trumping Missouri's concerns about limitations on Congress's enumerated powers and abrogation of states' rights).

98 See, e.g., Cty. of Santa Clara v. Trump, 250 F. Supp. 3d 497 (N.D. Cal. 2017) (granting preliminary injunction and finding likelihood of success on the merits of the plaintiffs' claim that President Trump's Executive Order 13768 [threatening to defund "sanctuary jurisdictions"] is unconstitutional on the grounds that it violates both horizontal and vertical separation of powers concerns); City \& Cty. of S.F. v. Trump, No. 17-16886, 2018 U.S. App. LEXIS 239 (9th Cir. Jan. 4, 2018) (upholding the district court's permanent injunction on the defunding and enforcement provisions of the executive order); Cty. of Santa Clara v. Trump, 267 F. Supp. 3d 1201 (N.D. Cal. 2017) (concluding that the U.S. Attorney General's Memorandum clarifying Trump's executive order does not change the analysis from the PI Order, and therefore denying the government's motions for reconsideration); see also City of Seattle v. Trump, No. 17-497-RAJ, 2017 U.S. Dist. LEXIS 173376 (W.D. Wash. Oct. 19, 2017) (denying the Government's motion to dismiss because plaintiffs are likely to succeed in showing that the Executive Order is unduly coercive, discriminatory, and unconstitutional); City of Chicago. v. Sessions, 264 F. Supp. 3d 933 (N.D. Ill. 2017) (granting a preliminary injunction against the Attorney General's imposition of notice and access conditions on the Byrne JAG grant because if imposed, the City of Chicago will face irreparable harm regarding its immigration policies).

99 See, e.g., Massachusetts v. EPA, 549 U.S. 497 (2007) (agreeing with Massachusetts and the other states, the Court found the federal EPA's rationale for not regulating particular 
Placing this in transnational perspective, when democratic institutions have been under assault in other countries-such as in South Africa, Chile, and China-those who have sought to restore or establish democracy have mobilized resistance to misguided policies not only below the level of the nation-state, but also horizontally and transnationally with partners abroad. 100

From time immemorial, even smaller political subunits, such as cities, have played an important role shaping the world- "[f]rom Athens and Rome to Paris and Venice to Baghdad and Beijing." 101 With state, county, and local governments across the United States paving the way as policy innovators-addressing global dilemmas posed by climate disruption and immigration-the old adage "act local, think global" might apply here. However, these subnational actors have an eye to the national, as much as they are looking to the global. Whether seeking to influence or resist the national agenda, these subnational governments seek to catalyze policy with the federal government, with each other, with their own constituents and interest groups (including business, etc.), and (at least with climate policy) with counterparts abroad.

\section{E. International Law as a Corrective to Political Market Failure}

While federalism can play an important role in addressing political market failures from below (and partnering transnationally with allies abroad plays a role horizontally), international law is designed to address such failures from above. A primary objective of international law is to address collective action failures (such as climate change).

greenhouse gas emissions from motor vehicles under the Clean Air Act to be inadequate and required the agency to articulate a reasonable basis in order to avoid regulation).

$100 \mathrm{I}$ am not equating the United States with these countries-as each country is unique-but am mentioning these other examples as a way of illustrating how this notion is not an abstract one. Consider, for example, how during apartheid in South Africa, the movement for a postapartheid democracy occurred primarily below (at the grassroots) and above (through an international anti-apartheid movement) the nation-state, which eventually helped dismantle national apartheid policies and transition to a nonracial democracy and new constitutional framework.

101 Michael Bloomberg, Why Municipalities Are the Key to Fighting Climate Change, FOREIGN AFF., Sept./Oct. 2015, at 1. 
Thus, international law is sometimes used to address the problems of regulatory capture and externalization of negative costs.

In the aftermath of World War II-and the Nazi Holocaustinternational law also brought global scrutiny to how countries treated their own citizens as well as foreign nationals-questions once considered the exclusive domain of the nation-state. As discussed supra, international human rights treaties include minority protections as central concerns. ${ }^{102}$ Therefore, international human rights law is frequently deployed to address the problem of minority underrepresentation-the very concern that is at the heart of Ely's theory.

While in theory, international law aims to both address collective action problems (such as climate change) and protect underrepresented minorities (such as immigrants), in practice, as discussed further below, international regulation often mirrors similar market failures reflected in the United States (and other countries). After all, international law is a system of states. Thus, not surprisingly, the market failures that are endemic within the nation-state are often projected to the international level.

Even so, because the goal of international law is to address such failures, global governance has the potential to respond-where nationstates acting alone (in an uncoordinated fashion) are not able to-for a few reasons. First, global governance can address collective action failures, including where public goods (such as the environment) are at stake, by getting all countries on board, to move beyond prisoner's dilemmas, so long as defections can be detected and addressed. Second, because everyone is likely a "minority" somewhere in the world (and behind the Rawlsian veil of ignorance, we are all potential minorities somewhere), international law can protect minority interests-at least conceptually (if not always effectively in terms of enforcement)-where national governments occasionally fail to (as in the case of genocide or other extreme governance failures). Finally, while many democraticallyelected leaders participate in the international system-and so there is at least some degree of democratic accountability-international law is often criticized as suffering from democratic deficits. However, the fact that international governance regimes are not directly democratic helps

102 See supra note 42. 
to guard against the various tyrannies of majorities that we are so familiar with in national politics. This too is a safeguard, particularly as we consider that contemporary international law largely grew out of World War II and the extreme abuses of nationalism in Nazi Germany.

\section{F. Limitations of this Approach}

It is important to acknowledge limitations to the approach I am outlining in this Article. First, while international law can be long on principle, it is often short on enforcement. ${ }^{103}$ Second, while this Article is somewhat trans-substantive, I am limiting this Article to climate change and sanctuary policies. Though the ideas I introduce may have relevance for other federalism disputes involving transnational issues, I am not, at this juncture, extending my approach beyond the two case studies analyzed here.104 Even assuming the ideas discussed in this Article are limited to these two matters, climate change and immigration are large enough dilemmas to warrant fresh thinking on their own.

Third, to the extent that this Article focuses on sub-federal climate and sanctuary innovations that represent forms of resistance to federal policy, it is critical to note at the outset the diversity of policies in both areas, and that many jurisdictions are oriented toward various forms of cooperation (if only unwittingly) or are engaged in a mix (or patchwork) of various forms of cooperation and resistance. 105 While by

103 Catharine MacKinnon makes this observation by noting:

Briefly put, the applicable international law was strong in principle but weak on delivery. Domestic law in many countries had the reverse problem. It was often short on principle by international standards but long on teeth. We concluded that if you want a statement of principle, go to an international forum; if you want delivery, go to a national court.

Catharine A. Mackinnon, Remedies for War Crimes at the National Level, J. INT'L INST., Fall 1988, at 23, https://quod.lib.umich.edu/j/jii/4750978.0006.103/-remedies-for-war-crimes-atthe-national-level?rgn=main;view=fulltext [https://perma.cc/DUX7-RZRJ].

104 As discussed in the Introduction, supra, other federalism debates, such as those involving the legalization of marijuana and guns policy, have transnational dimensions. However, neither is inherently transnational in the way climate and immigration policy are.

105 The state of Texas, for example, prohibits sanctuary jurisdictions (under SB4), even while a number of cities within the state have proclaimed themselves sanctuaries. 
some measures, the adoption of sub-federal policies resisting aspects of federal climate and immigration policies has accelerated since the 2016 election, in many (and perhaps in most respects), subnational jurisdictions continue to cooperate with the federal government. It is also vital to recognize that the roots of both resistance and cooperation pre-date the 2016 election and actually go back for years. 106

Lastly, the claims in this Article are not intended to suggest that jurisdictions engaged in forms of resistance will inevitably win the day or that progress (in whatever way one defines it) is linear. "[T]he arc of the moral universe" might "bend[] toward justice," 107 but the history suggests that the efforts examined in this Article (to either protect disadvantaged minorities or curb the influence of influential minorities) inevitably experience cycles of progress and retrenchment and can never be taken for granted as settled.

\section{Climate Change Federalism}

This Part examines how, by shifting from a top-down, centralized approach to a bottom-up, decentralized governance approach, environmental governance now has the potential to more effectively address the problem of regulatory capture both above and below the nation-state. Other scholars have observed this shift in environmental governance, but what this Article adds is how the shift to bottom-up fits into a theory of challenging political market failure. As discussed in Part I, international law is made by nation-states qua nation-states. Moving beyond the "black box" theory of the nation-state, we can view the positions that countries take in negotiating and creating legal standards on the international stage as reflecting political preferences in domestic

106 For helpful discussion of this history in the climate change context, see Ann E. Carlson, Iterative Federalism and Climate Change, 103 Nw. U. L. REV. 1097 (2009). For a valuable overview of the history of the sanctuary jurisdictions movement, see Annie Lai \& Christopher N. Lasch, Crimmigration Resistance and the Case of Sanctuary City Defunding, 57 SANTA CLARA L. REV 539, 546-48 (2017) (discussing how sanctuary policies have proceeded in four successive waves).

107 Matt Lewis, Obama Loves Martin Luther King's Great Quote-But He Uses It Incorrectly, DAILY BEAST (Jan. 16, 2017, 12:15 AM), https://www.thedailybeast.com/obama-loves-martinluther-kings-great-quotebut-he-uses-it-incorrectly [https://perma.cc/V6WZ-BA4V]. 
politics. ${ }^{108}$ Because global environmental governance-like most international governance-mirrors the preferences of nation-states (and, in turn, the domestic political interests of those in power in various countries), historically, global environmental regulation suffered from similar problems (as domestic policy) of regulatory capture, but at the global scale. By combining insights from international relations (IR) and federalism scholars, this Part analyzes how new models of governance-which challenge the exclusive role of the federal government in environmental law-can address shortcomings of both international and national governance.

Despite ample evidence of climate change, the Trump administration is rolling back federal commitments to mitigate its effects and has sought to undermine climate research. ${ }^{109}$ Research provides the basis for knowledge and information, and by undermining support for research, the federal government is affirmatively reinforcing the problem of information asymmetries. Science denialism appears to be based on the regulatory capture of the federal government by the coal industry110 (and plays into the broader trend toward creating a "posttruth" society).

\footnotetext{
108 Under a traditional, realist view of international law and international relations, scholars conceived of the nation-state as an undifferentiated "black box," rather than look inside the box to examine how domestic politics impact the positions national governments take internationally. In this view, countries interact as "billiard balls" on a pool table, knocking up against each other, rather than influencing and reshaping each other's preferences and interests. See Putnam, supra note 29 (recognizing that national-level policymakers face constituencies at both domestic and international levels and exploring the dynamic interaction between the two in international negotiations); see also Anne-Marie Slaughter, International Relations, Principal Theories, in 6 The MAX PLANCK ENCYCLOPEDIA OF PUBLIC INTERNATIONAL LAW 129 (Rüdiger Wolfrum ed., 2013) (contrasting realist with other theories of international law and international relations).

109 On efforts to undermine climate change research, see supra note 92. For a summary of scientific evidence regarding climate change, see infra notes 112-13 and accompanying text. For a discussion of the federal government's dramatic reversal on climate policy-with the transition from President Obama to President Trump, see infra Section II.A.5.

110 As discussed infra in Section I.B, evidence of the political influence of the fossil fuel companies is apparent from the fact that former lobbyists for coal and other fossil fuel companies are now in senior positions at the EPA, implementing policies they pushed for while in the private sector-a dubious practice that raises ethical and legal concerns regarding restrictions on lobbying.
} 
Section II.A discusses how global environmental regulation has shifted from a traditional top-down regulatory approach to a bottom-up catalytic governance approach 111 and explores how this shift helps address governance failures at the global level. Section II.B examines how a similar dynamic is at work with regard to domestic climate policy. Section II.C extracts the lessons gleaned from global environmental governance and IR scholarship to clarify further how sub-federal policy innovation can address the political market failures that are apparent in climate policy.

Scientific research demonstrates that rising sea levels are increasing the risk of catastrophic flooding; that shifting weather patterns threaten food production and even water; and that we are already experiencing some of the cataclysmic effects of climate change, particularly in coastal areas. ${ }^{112}$ Furthermore, as overdevelopment, population growth, and climate change upset the balance between water use and supply, urban centers across the globe-from Cape Town to Los Angeles to Beijingincreasingly face longer, more frequent, and more unpredictable droughts and severe drinking-water shortages.113 The impacts could challenge the planet's ability to support life as we know it.

\section{A. The Shift in Global Environmental Governance at the Global Level}

This Section discusses how global environmental governance has shifted from a traditional top-down regulatory approach to a bottom-up catalytic governance approach, and explores how this shift helps address

111 I am borrowing the dichotomy between "regulatory" versus "catalytic" approaches from Thomas E. Hale, Catalytic Institutions for the Global Commons: Tragedy or Tipping Point?, FUTURE GLOBAL ORDER COLlOQUIUM (2017), https://global.upenn.edu/sites/default/files/ halepaper.original.pdf [https://perma.cc/8SGF-JG4R].

112 Climate Change, United NATIONS: GlObaL ISSUES, http://www.un.org/en/sections/ issues-depth/climate-change [https://perma.cc/L68W-9ALL] (last visited May 24, 2019); Hale, supra note 111, at 17.

113 Nita Bhalla, World Has Not Woken Up to Water Crisis Caused by Climate Change, SCI. AM. (Feb. 3, 2015), https://www.scientificamerican.com/article/world-has-not-woken-up-towater-crisis-caused-by-climate-change [https://perma.cc/9LQB-A8NL]; Scott Moore, On 'Day Zero,' Cape Town Will Run Out of Water. It's Not the Only City at Risk, WASH. Post (Feb. 5, 2018), https://www.washingtonpost.com/news/monkey-cage/wp/2018/02/05/on-day-zero-capetown-will-run-out-of-water-other-cities-are-in-the-same-boat/?utm_term $=.084 \mathrm{bfc} 874587$ [https://perma.cc/VFL8-WZN4]. 
political market failures in global governance. Subsection II.A.1 provides an overview of the mechanics and importance of this shift. Subsection II.A.2 describes the governance shortcomings of the traditional top-down regulatory approach. Subsection II.A.3 examines the transition from the traditional to the bottom-up governance approach. Subsection II.A.4 reflects on how the 2015 Paris climate change agreement marked the full emergence of a bottom-up catalytic governance approach. Subsection II.A.5 discusses the commitments then-President Obama made under the Paris accord, as well as steps President Trump has taken to pull back from these commitments.

\section{The Need for Reform and Overview of the Shift}

The largely ineffective ability of traditional international law to address a range of environmental challenges paved the way for new models of global environmental governance. ${ }^{114}$ As Eric Orts notes, "[g]lobal environmental governance refers to the institutional and individual capacities that affect how human interactions contribute to either causing or alleviating environmental problems, including various kinds of pollution." 115 Many environmental law scholars note that climate change is a global environmental problem requiring not only strategies of mitigation, but also strategies of adaptation and resilience. 116

114 See Tseming Yang \& Robert V. Percival, The Emergence of Global Environmental Law, 36 ECOLOGY L.Q. 615 (2009).

115 Eric W. Orts, The Reformation of Global Environmental Governance: Addressing the Challenge of Climate Change, FUTURE Global ORder COlloquium 2 (2017), https:// global.upenn.edu/sites/default/files/go-reformation-of-global-orts.original.pdf [https:// perma.cc/6JVK-MMC3].

116 See, e.g., Engel, supra note 19, at 75-76.

[A]daptation is usually understood as the minimization of harms resulting from climate change that will occur despite whatever mitigation measures are being taken. In view of this, many believe the objective of adaptation should be resilience ... the "capacity of an ecosystem to withstand disturbance and maintain the same basic processes and structures" or "the ability of a system to return to its initial state and function in spite of some major perturbation." Commentators generally agree that regulatory approaches should seek to reduce the vulnerability of ecosystems to abrupt and uncertain change and to reinforce the resiliency of such systems so that they survive the onslaught of climatic changes. 
A more traditional international environmental law approach focused on top-down implementation by the nation-state-and international agreements among nation-states. By contrast, the new global environmental governance approach transcends this and moves toward a bottom-up approach to account for roles played by not only national governments, but also other organizations, including subnational governments, corporate firms, non-governmental organizations, and international organizations. ${ }^{117}$

The road from the 1992 Rio Earth Summit to the 2015 Paris Agreement illustrates a shift from the more traditional, top-down, "regulatory" approach to a more polycentric, bottom-up, "catalytic" approach. 118 While different scholars describe this shift in various ways, I am drawn to the regulatory/catalytic dichotomy utilized by IR scholar Thomas Hale. 119 This fits within the shift Professor Orts discusses (from traditional international environmental law to global environmental governance) and the dynamics that Sabel and Victor discuss, 120 but goes further by providing a deeper conceptual basis for understanding why the shift in approach has been beneficial in realizing the climate change mitigation goals and addressing shortcomings in global regulation, where past efforts failed.

By "regulatory institutional approach," Hale refers to top-down "collective agreement[s] [among national governments] to proscribe [at the global level] what each country is allowed to do and aims to detect and punish non-compliance." 121 In theorizing the notion of a catalytic, bottom-up approach, Hale explains that the problem structure of global climate mitigation can be understood not only as a tragedy of the commons, but also more precisely as a tipping problem. ${ }^{122}$ After all, the chief barrier to cooperation is not necessarily the threat of free-riding, but the lack of incentive to act in the first place. States and other actors

Id.

117 Orts, supra note 115, at 2. See also Charles F. Sabel \& David G. Victor, Governing Global Problems Under Uncertainty: Making Bottom-Up Climate Policy Work, 144 ClimatiC Change 15 (2017).

118 Orts, supra note 115, at 1-2; Hale, supra note 111, at 4-10.

119 Hale, supra note 111.

120 See Orts, supra note 115, at 1-2; Sabel \& Victor, supra note 117.

121 Hale, supra note 111, at 5.

$122 I d$. at 1. 
seek to solve this problem by creating "catalytic institutions," which "shift actors' preferences and strategies toward cooperative outcomes over time." 123

In fact, the bottom-up and polycentric nature of such initiatives is essential to this catalytic approach and its ability to enhance compliance with international law norms concerning climate change. Here, it is useful to draw, by analogy, to Michael Dorf and Charles Sabel's notion of "directly deliberative polyarchy" in their classic work on democratic experimentalism, wherein jurisdictions are encouraged to take ownership, benchmark progress against particular goals, experiment, use transparency to encourage participation, and make improvements over time in learning-by-doing. ${ }^{124}$ In this vein, scholars have noted the emergence of sub-federal governments (along with businesses, nongovernmental organizations, and other non-state actors) that are engaged in climate change policy in a directly deliberative way and, as Nobel political economist Elinor Ostrom noted, in a polycentric mode ${ }^{125}$ - and, I would add, in an increasingly networked mode. In addition to an emergence of multiple, overlapping climate regimes-or "regime complexes"126_there is a rise of multiple actors and venues for deliberation. As Hale notes:

Indeed, there has been such a proliferation and pluralisation of climate governance... in which governance and action occur in

123 Id. (emphasis added to underscore the dynamic of catalyst, which means not only to trigger, but also to increase the rate over time).

124 Dorf \& Sabel, supra note 33, at 288 ("The system in which citizens in each locale participate directly in determining and assessing the utility of the services local government provides, given the possibility of comparing the performance of their jurisdiction to the performance of similar settings, we will call directly deliberative polyarchy."). Dorf and Sabel further note: "This term and the ideas associated with it are developed in the eponymous companion piece by Joshua Cohen [and] Charles Sabel." Id. at 315 n.118 (citing Joshua Cohen \& Charles Sabel, Directly Deliberative Polyarchy, 3 EUR. L.J. 313 (1997). See also ROBERT A. DAHL, DEMOCRACY AND ITS CRITICS 221-22 (1989).

125 See Elinor Ostrom, A Polycentric Approach for Coping with Climate Change, 15 ANNALS ECON. \& FIN. 97 (2014), http://aeconf.com/articles/may2014/aef150103.pdf [https://perma.cc/ YSF4-B7N8].

126 Robert O. Keohane \& David G. Victor, The Regime Complex for Climate Change, 9 PERSP. ON POL. 7 (2011), https://www.cambridge.org/core/journals/perspectives-on-politics/ article/the-regime-complex-for-climate-change/F5C4F620A4723D5DA5E0ACDC48D860C0 [https://perma.cc/N2FH-KEGC]. 
myriad ways through many different coalitions that range in scale from global to local.... Polycentrism argues that "climate change" encompasses many interlocking sub-issues that manifest differently across contexts. ${ }^{127}$

To understand the broader context in which state and local climate change initiatives arise in the United States, it is useful to trace the shortcomings of the traditional, top-down, "regulatory" approach, before turning to the transition to the more decentralized, bottom-up, "catalytic" approach.

\section{The Traditional Regulatory Approach: From Rio to Kyoto}

At the 1992 Rio Earth Summit, countries adopted the U.N. Framework Convention on Climate Change (UNFCCC or Framework Convention), 128 reflecting a traditional regulatory approach to international governance. The UNFCCC was aimed at preventing "dangerous" human interference with the Earth's climate, caused by the emission of carbon dioxide and other greenhouse gases (GHGs). ${ }^{129}$ The Rio process followed the "convention + protocol" template, which characterizes not only global environmental governance, but also other areas of international law, in which "countries agree [upon] a framework convention to identify a problem and create a negotiating process through which member states then work to agree [on] a series of protocols that collectively bind them to specific commitments." 130 Hale refers to this as a "regulatory" approach, since it seeks top-down agreement among national governments to define standards. ${ }^{131}$

Following the 1992 Rio Summit's adoption of the Framework Convention, countries eventually agreed to devise a protocol, resulting in the 1997 Kyoto Protocol.132 The Kyoto Protocol required wealthy

\footnotetext{
127 Hale, supra note 111 , at 7-8.

128 United Nations Framework Convention on Climate Change, May 9, 1992, 1771 U.N.T.S. 107 (from Rio Earth Summit Conference).

129 Id. pmbl., g 2; id. art. 2.

130 Hale, supra note 111 , at 4-5.

131 Id. at 5.

132 Kyoto Protocol to the United Nations Framework Convention on Climate Change, Dec. 11, 1997, 2303 U.N.T.S. 162.
} 
countries to reduce emissions and created an emissions trading system as well as other forms of flexibility to permit wealthy nations the option of reducing emissions in poorer countries as a way of claiming reductions against their own targets. ${ }^{133}$ However, once George W. Bush became president, the United States retreated from the Kyoto Protocol in 2001 and, in any event, it was "soon outpaced by the rapid industrialization of emerging economies." 134

Noting the governance shortcomings of Kyoto, Professor Orts contends, "the Kyoto style of organizing nation-states to address climate change by a treaty or other formal 'top-down' arrangement foundered" for a couple of reasons, 135 which he mainly relates to the tragedy of the commons and free rider problems that Garrett Hardin famously identified. ${ }^{136}$ First, the Kyoto approach involved disagreement about how to conceive of both the nature of the problem and how to most fairly and effectively design the solutions, given several factors. The complexity of many nations with conflicting interests and values led to competing economic interests and controversy over the "ethics of comparative responsibility" among countries (for example, about how much the largely rich countries who had historically gained from industrial and other policies adverse to the climate should compensate those largely poorer countries who had not benefited).137

133 For a more detailed explanation of how emissions trading in particular works, see Emissions Trading: The Carbon "Market", UNFCCC, https://web.archive.org/web/ 20070106223133/http://unfccc.int/kyoto_protocol/background/items/2880.php (last visited Apr. 13, 2019):

Nations that have contributed the most to global warming have tended to benefit directly in terms of greater business profits and higher standards of living [and yet] [t]he negative effects of climate change will be felt all over the world, and actually the consequences are expected to be most severe in least-developed nations which have produced few emissions.

Id. The largely more industrialized nations will get credit for reducing greenhouse-gas totals in a number of ways, including for projects they support under the Protocol's Clean Development Mechanism, which can fund activities to reduce emissions by developing nations. "Credits earned this way may be bought and sold in the emissions market or 'banked' for future use." Id.

134 Hale, supra note 111, at 2.

135 Orts, supra note 115 , at 1.

136 Id.; Garrett Hardin, The Tragedy of the Commons, 162 SCI. 1243 (1968).

137 Orts, supra note 115, at 1; see also Hale, supra note 111, at 5 (observing that related to these fundamental disagreements between rich and poor nations, the United States and China in particular quarreled over who bore responsibility). 
Second, solutions needed to be conceived of in a way that accounts for variation across both space and time. After all, "[s]ome countries are [] more vulnerable to climate risks than others." 138 Plus, "the short attention spans of most human beings do not easily engage rationally with long-term climate consequences." 139 Finally, not only are mechanisms for monitoring and enforcing global standards for GHGs weak, but it is also challenging to determine how international regulation can best address "the economic phenomenon of 'leakage'i.e., the displacement of climate unfriendly production to non-regulated jurisdictions." 140

Following Kyoto-and even before the political emergence of Trump,

[W]e have seen slow progress, and even reversals of progress in countries such as the United States, because of general scientific ignorance, a cultural divide between scientist and policymakers, the politicization of science (and the advent of "alternative facts"), the organized denial of science, and partisan politics driven by business interests that would be affected negatively by climate mitigation policies. ${ }^{141}$

\section{The Transition from the Regulatory to Catalytic Approach}

Given these governance shortcomings-and in light of the "faltering regulatory approach," two alternatives emerged during the transition from Kyoto to the Paris Agreement: a "club" approach and a "polycentric" approach. ${ }^{142}$

\footnotetext{
138 Orts, supra note 115 , at 1.

139 Id.

$140 I d$. For a fuller treatment of these points, see Eric W. Orts, Climate Contracts, 29 VA. ENVTL. L.J. 197 (2011).

141 Orts, supra note 115, at 2 (citing Dale JAMIESON, ReASON IN A DARK Time: Why the Struggle Against Climate Change Failed-And What it Means for OUR Future 61104 (2014) for discussion of these and other challenges written prior to the most recent obstacles to addressing climate change illustrated by the Trump campaign and his administration).

142 Hale, supra note 111 , at 6-8.
} 
The Club Approach: The club approach built on the insight that while it is challenging to negotiate among over 190 nation-states, only a few dozen countries actually "mattered" for emissions purposes, and that limited membership institutions-like trade agreements-would have a better chance of securing cooperation, especially if such clubs could provide benefits for members that would then incentivize states to join.143 However, while this approach was attractive in theory, "in practice[,] climate clubs have struggled to identify excludable benefits because the atmosphere is inherently non-excludable." 144

The Polycentric Approach: The polycentric approach took advantage of the emergence of transnational networks of sub-state and non-state actors, including cities, businesses, environmental groups, and activists. As Hale observes:

[Polycentrism] may still be a tragedy of the commons at the global scale, but many actors[] will engage with specific aspects of the problem at different scales, such as a city focused on transport, a farming community focused on preserving their crops from drought, or a consortium of corporations seeking to preserve the sustainability of their supply chains. ${ }^{145}$

Envisioning information exchange across these various sites of governance operating in a polycentric mode, Professor Ostrom urged "methods for assessing the benefits and costs of particular strategies adopted in one type of ecosystem and [comparing these with] results obtained in other ecosystems." 146 The problem with polycentric structures, however, is that while they can "drive cooperation at

143 Id. at 6.

$144 \mathrm{Id}$. Hale notes proposals to link climate and trade, such as proposed carbon tariffs that would penalize laggards - the excludable benefit being avoiding the tariffs. However,

[t]he most serious attempt to impose a carbon tariff of this nature was the EU's modest proposal to require airlines using European airspace to pay a small carbon tax. $[\mathrm{T}]$ he proposal ... was vigorously opposed by the United States, China, and India, and eventually scrapped by European member states that did not want to pay the costs of friction with significant trading partners.

Id.

$145 I d$. at 8 .

146 Ostrom, supra note 125. 
multiple scales for those actors who wish to address [climate change, they] offer few solutions to compel recalcitrant actors." 147

\section{The Catalytic Approach: Paris Agreement and Beyond}

When President George W. Bush "unsigned" the Kyoto Protocol, 148 economist Thomas Schelling published a notable article in Foreign Affairs contending that Kyoto's regulatory regime was not workable, and calling for an approach based on iterative and flexible commitments. 149 In fact, the failure of the traditional regulatory approach did not lead climate change mitigation efforts to simply stagnate. Instead, "policy entrepreneurs radically changed the logic"150 of these efforts.

As Professor Orts flatly observes, "Kyoto is dead, and Paris has killed it." 151 While Kyoto involved a set of shared reduction targets through formal international legal agreements negotiated by nations, the Paris Agreement involved a conceptual shift. The 2015 Paris accord requires each nation to come forward with its own pledge, or "nationally determined contribution." These national pledges are then reviewed at the international level and ratcheted up on a periodic five-year basis. The goal is ambitious-to prevent no more GHGs entering the atmosphere than are absorbed-in effect, creating a decarbonized world by the second half of the century. To help facilitate the process, Paris provides a key role for sub-state and non-state actors, "creating

\footnotetext{
147 Hale, supra note 111 , at 8.

148 Note that the 1997 Kyoto Protocol was brokered by then-Vice President Al Gore and signed by then-President Bill Clinton. Similarly, President Trump's announcement that he intends to withdraw from Paris (or negotiate a better deal) follows President Obama's personal leadership role in clinching the Paris deal. Riley Beggin, The Last Time a US President Dumped a Global Climate Deal, ABC NEws (June 1, 2017, 4:42 PM), http://abcnews.go.com/Politics/ time-us-president-dumped-global-climate-deal/story?id=47771005 [https://perma.cc/9FJBLJ6X].

149 Thomas C. Schelling, What Makes Greenhouse Sense?, ForeIGN AfF., May/June 2002, at 2 (2002), https://www.foreignaffairs.com/articles/2002-05-01/what-makes-greenhouse-sense [https://perma.cc/H3P9-XJSP].

150 Hale, supra note 111 , at 2.

151 Orts, supra note 115, at 1.
} 
institutions to recognize and orchestrate their climate action alongside the national pledges." 152

In fact, early on during negotiations leading up to the Paris accord, the Obama administration rejected the more traditional, top-down approach-where treaty terms would have provided what was expected of states-parties. Partly, the Obama team thought reaching global consensus on such treaty terms would be nearly impossible. Plus, getting a treaty with legally binding commitments through the Senate did not seem entirely feasible politically, particularly where "most Republican Senators did not even [publicly] acknowledge the existence of the underlying problem of climate change." 153

At the same time, President Obama was ultimately committed to seeing the Paris process succeed. He noted that the two largest existential threats to humans and global civilizations are the potential threat of thermonuclear war (which remains in the realm of traditional statecraft by governments to manage) and climate change (which nation-states alone will not be able to address). ${ }^{154}$

The only non-signatories of the Paris Agreement-Syria and Nicaragua-eventually signed it. With Trump's announcement that he intends to pull the United States out of the agreement, "it would be the only country in the world outside the agreement." 155

The 2018 U.N. Climate Change Conference in Poland-climate talks marking the third anniversary of the Paris accord-reaffirmed Paris, taking steps toward "putting the 2015 Paris agreement into practice" by addressing issues such as "how governments will measure, report on and verify their emissions-cutting efforts," while still leaving it

152 Hale, supra note 111, at 2 (providing overview of main elements of the Paris accord).

153 Ann Carlson, Climate Change, Trump and Populism, FUTURE GLOBAL ORdER COLLOQUIUM 2 (2017), https:/global.upenn.edu/sites/default/files/go-climate-changecarlson.original.pdf [https://perma.cc/C2B5-T5VQ].

154 Orts, supra note 115, at 1. Orts cites Thomas L. Friedman, 'Trump's Folly', N.Y. TIMES, Sept. 13, 2017, at A27, stating "off-the-record interview with a person familiar with President Obama's daily briefings in the Oval Office" and "describing the risks of nuclear war such as with North Korea and the risks of global climate change suggested by Hurricanes Harvey and Irma as two leading national security threats." Id. at $1 \mathrm{n} .1$.

155 Alexandra Simon-Lewis, What Is the Paris Climate Agreement and Who Has Signed It?, WIRED (Nov. 7, 2017), http://www.wired.co.uk/article/what-is-paris-agreement-on-climatechange [https://perma.cc/UNZ7-KRRY]. 
to states in 2020 to choose their own new, tougher targets. ${ }^{156}$ The United States agreed to the deal in Poland, despite Trump's vow to abandon the Paris accord, prompting diplomats and climate change activists to hope that the administration may "change its mind and stay in the Paris Agreement, or for a future president to embrace the accord once again."157

5. U.S. Paris Commitments and Trump's Threatened Withdrawal

While the new governance approach ushered in by the Paris climate change agreement has garnered participation by every single country in the world-including meaningful participation by the world's largest economies-President Trump signaled his intention to withdraw from the accord. To understand what he may be walking away from, this Subsection provides a brief overview of the primary elements of the United States' pledges pursuant to the agreement. In its nationally determined commitment (NDC), the United States pledged to reduce emissions by $26 \%$ to $28 \%$ below 2005 levels by 2025 . This pledge includes five main components, each of which is under threat by the Trump administration, court action, or both: 158

The Clean Power Plan: The Clean Power Plan was Obama's signature commitment under the Paris Agreement. The Plan involved cutting emissions from power plants by $32 \%$ by 2030 . While the power sector is the second largest source of greenhouse gases in the countrybehind transportation-the cuts in power plant emissions would be greater than from the transportation sector, making the commitment outsized in importance. In August 2018, Trump's EPA “proposed replacing the [Clean Power Plan's] rule on carbon dioxide pollution from coal-fired power plants with a weaker one that would allow far

156 Fiona Harvey, What Was Agreed at COP24 in Poland and Why Did It Take So Long?, GUARDIAN (Dec. 16, 2018, 7:04 AM), https:/www.theguardian.com/environment/2018/dec/16/ what-was-agreed-at-cop24-in-poland-and-why-did-it-take-so-long [https://perma.cc/R4RCPELH].

157 Brad Plumer, Climate Negotiators Reach an Overtime Deal to Keep Paris Pact Alive, N.Y. TiMES (Dec. 15, 2018), https://www.nytimes.com/2018/12/15/climate/cop24-katowice-climatesummit.html [https://perma.cc/JS2L-T2BQ].

158 This summary draws on (and updates) a summary outlined in Carlson, supra note 153, at $2-3$. 
more global-warming emissions to flow unchecked from the nation's smokestacks." 159

Higher Fuel Economy Standards: The second most significant commitment is the pledge to strengthen fuel efficiency standards in cars and trucks. In August 2018, the Trump administration unveiled its plan to relax auto emission restrictions, weakening Obama-era regulations to curb pollution by requiring increased fuel-efficiency standards for cars. 160

The proposed new rules would also challenge the right of states, in particular California, which, under waivers from the federal government, had been able to set its own, more stringent tailpipe pollution standards. Given the problem of automobile pollution in California, the commitment to reducing car emissions in the state has been bipartisan. In 1967, then-California State "Governor Ronald Reagan signed legislation creating the powerful California Air Resources Board to regulate air pollution statewide, including by strictly curbing vehicle emissions." 161 The Trump administration proposal would revoke the California waiver, granted under the 1970 Clean Air Act-and followed by a dozen states and the District of Columbia-which allows states to set pollution standards that are more stringent than the federal government's standards. ${ }^{162}$ The plan to revoke the waiver sets the stage for a legal conflict that could split the nation's auto market in two"[o]ne for California and the dozen other aligned states that account for one-third of the U.S. auto market, and another for the rest of the country"163-a situation that auto companies themselves have said they

159 Id.; Davenport, supra note 80; see also Lipton, Dirtiest Coal, supra note 80; Friedman, supra note 91; What Is the Clean Power Plan, and How Can Trump Repeal It?, N.Y. TimES (Oct. 10, 2017), https://www.nytimes.com/2017/10/10/climate/epa-clean-power-plan.html [https:// perma.cc/6XXM-D38B].

160 Davenport, supra note 91.

161 Jody Freeman, Trump's Biggest Climate Move Yet Is Bad for Everyone, N.Y. TimEs (Aug. 2, 2018), https://www.nytimes.com/2018/08/02/opinion/trumps-biggest-climate-move-yet-isbad-for-everyone.html?action $=$ click\&module $=$ RelatedCoverage\&pgtype $=$ Article $\&$ region=Footer [https://perma.cc/J3VW-HES4].

162 Tony Barboza, California Counters Trump on Car Emissions Standards, Expands Other Climate Rules, L.A. Times (Sept. 28, 2018, 4:55 PM), http://www.latimes.com/local/lanow/lame-carbon-fuels-20180928-story.html [https://perma.cc/2FMM-7Y55].

163 Id.; Miranda Green, California Sues Trump Administration for Details on Car Emissions Rollback Decision, HILL (Apr. 8, 2019, 12:06 PM), https://thehill.com/policy/energy- 
want to avoid.164 Following a breakdown in negotiations between California and the federal government in February 2019, California sued the Trump administration for details behind the administration's decision to lower auto emissions. ${ }^{165}$

Stricter Appliance Efficiency Standards: The Obama administration issued more stringent efficiency standards for twenty-nine different categories of equipment and appliances, such as air conditioners and compressors, in order to reduce energy consumption. By refusing to allow agencies to submit the regulations for publication in the Federal Register, the Trump administration has, in effect, frozen the implementation of these standards. ${ }^{166}$

Reductions in Methane from Landfills and Oil and Gas Operations: The Obama administration adopted new regulations, one to reduce methane from landfills, as well as others to reduce emissions from oil and gas operations on public lands. 167 Along with carbon dioxide, methane is a "potent greenhouse gas ... considered a primary driver of global warming." 168 The Obama-era rule, which was never permitted to go into effect once Trump came to office, "would have required oil and gas companies to capture leaked methane, repair outdated leakdetection equipment and come up with new plans to reduce waste." 169

environment/437839-california-sues-trump-admin-for-details-on-car-emissions-rollback [https://perma.cc/J8JE-VDPV] ("Thirteen states follow California's standards for cars sold in their borders, representing about 40 percent of the nation's vehicle market.").

164 The Trump administration "proposal goes much further than many major automakers wanted, and manufacturers are now worried that years of legal challenges and regulatory uncertainty could complicate their business." Davenport, supra note 91.

165 Green, supra note 163; see also Ryan Beene, White House Warns Carmakers on Emissions in Tense Call, BloOMBerg (Mar. 6, 2019, 4:00 AM), https:/www.bloomberg.com/news/articles/ 2019-03-06/white-house-to-automakers-it-s-trump-or-california-on-emissions ("The White House has issued an us-versus-them challenge to carmakers: back an administration plan to roll back fuel-economy standards or risk President Donald Trump's wrath by siding with California's stringent emissions requirements.").

166 Carlson, supra note 153, at 2.

167 Id.

168 Lisa Friedman, Trump Administration Formally Rolls Back Rule Aimed at Limiting Methane Pollution, N.Y. TIMEs (Sept. 18, 2018), https://www.nytimes.com/2018/09/18/climate/ trump-methane-rollback.html [https://perma.cc/3ZCB-HGGB].

$169 I d$. (explaining that " $[\mathrm{h}] \mathrm{ad}$ it been finalized, it would have cut methane from the oil and gas sector by as much as 35 percent and helped the United States to achieve its greenhouse gas emissions goal under the global Paris Agreement on climate change."). 
However, in September 2018, the Trump administration reversed the Obama-era regulation "that would have reduced leaking, venting and flaring of methane from drilling activity on federal and tribal land." 170 The Trump administration's approach makes it significantly easier for energy companies to release methane into the atmosphere, and "energy companies have long said that the rules requiring them to test for emissions were costly and burdensome." 171

Reductions in High Global Warming Potential Hydrofluorocarbon: Initially, the Trump administration appeared to support an Obama-era rule requiring the phase-out of certain uses of hydrofluorocarbons (HFCs) - a particularly potent GHG used in air-conditioners and refrigerators. Honeywell and DuPont Chemical's spinoff, Chemours Company, supported the rule, which Professor Ann Carlson notes may help explain the Trump administration's support for the rule. ${ }^{172}$ The fact that the Trump administration seemed inclined to maintain this last pledge made by Obama (which chemical companies actually supported) - but not the other four commitments Obama made toward the Paris accord-underscores the points I make above in Part I about regulatory capture. However, in the aftermath of a D.C. Circuit ruling holding that the EPA exceeded its authority in issuing the rule, ${ }^{173}$ the Trump administration proposed a new rule rescinding even this Obama-era regulation. ${ }^{174}$

$170 I d$.

171 Davenport, supra note 80.

172 Carlson, supra note 153, at 2 (noting, however, that the D.C. Circuit "recently struck down the rule on the grounds that EPA lacked the authority to issue it under the Clean Air Act.").

173 Mexichem Fluor, Inc. v. EPA, 866 F.3d 451 (D.C. Cir. 2017).

174 Miranda Green, EPA to Abandon Restrictions Against Chemical Linked to Climate Change, HiLl (Sept. 20, 2018, 12:38 PM), https://thehill.com/policy/energy-environment/ 407614-epa-to-abandon-restrictions-against-climate-change-linked-chemical [https:// perma.cc/A9L6-U959]. For more detail, see Russ LaMotte et al., EPA Proposes Rescinding Certain HFC Rules for Refrigeration and Air-Conditioning Appliances, BEVERIDGE \& DIAMOND PC (Sept. 27, 2018), https://www.bdlaw.com/publications/epa-proposes-rescinding-certain-hfcrules-for-refrigeration-and-air-conditioning-appliances [https://perma.cc/7SCP-VCQL]. 


\section{B. "We the People" and Climate Change at the Domestic Level}

This Section examines how a somewhat similar bottom-up, catalytic approach has unfolded in domestic climate policy. State and local governments in the United States have a long history of involvement in addressing climate change and in spurring the federal government to act-a dynamic that Professor Carlson has called "iterative federalism." 175 As discussed below, what is new since President Trump's announcement to withdraw from the Paris Agreement is the ways in which state and local officials have stepped forward to directly engage global environmental governance in a visible, coordinated, and networked fashion. By attending international meetings of state parties to the Paris Agreement-and through their actions and statements at home-state and local government officials have pledged to fight for the commitments the United States has made through the Paris process, in the absence of federal leadership (and more to the point, in the presence of federal hostility).

In so doing, these state and local government officials are embracing a shared community (at least concerning our shared planet and climate) that is both local and global-and that concerns "We the People" today and "We the People" tomorrow (future generations). These leaders are forcefully rebutting the efforts of powerful economic interests to externalize their responsibility for the costs of climate change to the rest of us-both at home and abroad, for today's and future generations. ${ }^{176}$ The rest of us do not benefit from these economic interests but bear the brunt of the cost of climate change. While state and local officials have grounded their primary concerns in their unique local environmental priorities, these leaders have also linked these very concrete local concerns to the global (indeed planetary) phenomenon of climate change and the recognition that we are all in this together (in a quite existential way) and depend on cooperation with each other-for ourselves and future generations. 177

175 Carlson, supra note 106.

176 As discussed above, the failure to address climate change today externalizes its effects to future generations. See discussion supra note 83 and accompanying text.

177 See discussion infra Section II.C. 


\section{States and Localities to Trump: "Get Out of the Way"}

After Trump announced his intention to pull out of the Paris Agreement, the White House sent a small delegation in December 2017 to U.N. climate talks in Bonn, Germany-a meeting marking the second anniversary of the Paris accord.178 While the official U.S. delegation scheduled a meeting to discuss the future of coal, a high-level bipartisan, alternative coalition-including former New York City Mayor Michael Bloomberg, California Governor Jerry Brown, and several senators, mayors, and business leaders-launched the "America Pledge" report. ${ }^{179}$ Demanding a "seat at the table" in Bonn, Bloomberg-who is also a U.N. Special Envoy for Cities and Climate Change-said of the America Pledge group, "[i]f this group were a country, we'd be the third-biggest economy in the world." $180 \mathrm{He}$ went on to say, "[i]f Washington won't lead, then mayors and governors will." 181

California Governor Jerry Brown called on President Trump to start fighting climate change or to "get out of the way." 182 Citing recent violent wildfires in California as an example of extreme weather made worse by human-made climate change, Brown noted that "the fires are burning in California [and] [t]hey'll be burning in France, burning all around the world," if countries fail to reduce emissions. ${ }^{183}$

Former U.S. Secretary of State John Kerry attended the Bonn meeting as well, to reassure other countries at the summit that Americans are committed to fighting global warming. Noting that thirty-eight states have legislation supporting renewable energy, and

178 In fact, "rather than sending high-level Cabinet secretaries to the meeting as the Obama White House did, the U.S. delegation [was led] by Under Secretary of State for Political Affairs Thomas A. Shannon, Jr." Irfan, supra note 71.

179 Watts, supra note 3.

180 Id.

$181 \mathrm{Id}$. For an analysis of other ways that state and local governments have played a role in advancing international environmental and other policy goals, see, for example, BENJAMIN R. Barber, If Mayors Ruled the World: Dysfunctional Nations, Rising Cities (2013); William Boyd, Climate Change, Fragmentation, and the Challenges of Global Environmental Law: Elements of a Post-Copenhagen Assemblage, 32 U. PA. J. INT'L L. 457 (2010).

182 Brown to Trump, supra note 2.

183 Id. 
that ninety major American cities back the Paris accord, Kerry added, "[w]e're going to stay on track." 184

A group of 225 investment funds managing more than $\$ 26$ trillion in assets announced they were going to put pressure on companies to reduce their greenhouse gas emissions and disclose climate-related financial information. ${ }^{185}$ The coalition, called the Climate Action 100+ group, includes the California Public Employees' Retirement System, the largest U.S. public pension fund. ${ }^{186}$ The group says it will focus on 100 of the world's largest corporate GHG emitters. 187 Anne Simpson, investment director of sustainability at CalPERS, observed that getting major energy and transportation companies to align their future plans with the goals of the Paris Agreement could trigger action across all sectors as firms will seek to avoid being "left behind" by investors. 188

Moreover, in another bipartisan initiative led by Chicago Mayor Rahm Emmanuel (and supported by former New York City mayor Michael Bloomberg and former President Barack Obama), more than fifty mayors from across the United States and Canada participated in the North American Climate Summit in Chicago in December 2017. The group of mayors signed "an official agreement-the Chicago Climate Charter-in which they pledged to meet the emissionsreduction goals set out by the Paris agreement." 189 The Chicago Climate Charter builds on a pledge that Michael Bloomberg had made the year before that cities and businesses would lead on climate change, with or

\footnotetext{
184 Id.

185 Id.

186 Id.

187 Id.

188 Id. A similar initiative has been launched by New York City Comptroller, Scott Stringer. See Press Release, Scott M. Stringer, New York City Comptroller, Global Investors Launch Initiative to Wipe Out Carbon Pollution at Country's Largest Power Utilities (Feb. 28, 2019), https://comptroller.nyc.gov/newsroom/global-investors-launch-initiative-to-wipe-out-carbonpollution-at-countrys-largest-power-utilities [https://perma.cc/4Y8Z-78XU] ("As the push to decarbonize the U.S. economy accelerates, today New York City Comptroller Scott M. Stringer led a coalition of institutional investors representing some $\$ 1.8$ trillion in combined assets to demand the 20 largest publicly traded electricity generators in the U.S. commit to achieving net-zero carbon emissions.").

189 Jeremy Berke, More Than 50 US Mayors Just Signed a Charter to Meet the Paris Agreement Goals Without Trump, BUS. INSIDER (Dec. 12, 2017, 1:00 PM), http://www.business insider.com/paris-agreement-2-year-anniversary-us-mayors-step-up-2017-12 [https:// perma.cc/UX8L-8ECE].
} 
without the federal government's support. A group chaired by Bloomberg-the Global Covenant of Mayors-was partly responsible for organizing the Chicago event. 190

In September 2018, California Governor Brown hosted his own domestic climate change conference in San Francisco, featuring representatives of sub-national governments, businesses, investors, musicians, and others to highlight action that could "spur deeper commitment" from national governments to fight global warming. ${ }^{191}$ Along with governors from New York, Maryland and Connecticut, Governor Brown's team said they would work on new regulations to restrict hydrofluorocarbons. 192

Of course, "businesses would prefer a single federal standard, [but] even a few states acting together could create a significant market for cleaner alternatives to HFCs," according to the general counsel for one industry group, the Air-Conditioning, Heating, and Refrigeration Institute. ${ }^{193}$ A coalition of sixteen states, Puerto Rico, hundreds of cities, and almost 2,000 businesses, have pledged to ensure that the United States will meet former President Obama's Paris pledge to cut GHG emissions $26 \%$ to $28 \%$ below 2005 levels by $2025 .{ }^{194}$ However, the group has acknowledged that "United States emissions are on track to fall only about 17 percent over that span" and that these "states and cities would have to pursue ambitious new policies, like retrofitting hundreds of buildings to make them more energy efficient and plugging methane emissions from landfills, to get closer to the target," and persuade "several other states beyond the blue coastal enclaves to join them." 195

Action by a handful of localities alone will simply not be enough if we are to rescue the planet. Outlining the sheer scale of the challenge

$190 I d$.

191 Mythili Sampathkumar, California Launches New Climate Change Conference to Help Fulfill Paris Agreement Targets, InDEPENDENT (July 6, 2017, 11:17 PM), http:// www.independent.co.uk/news/world-0/us-politics/california-climate-change-conference-parisagreement-deal-targets-a7828076.html [https://perma.cc/DG5T-BJB2].

192 Brad Plumer, California Had Its Own Climate Summit. Now What?, N.Y. TIMES (Sept. 15, 2018), https://www.nytimes.com/2018/09/15/climate/california-climate-summit.html (noting "[i]n 2016, nations agreed on a treaty to phase out these gases, but Mr. Trump has not submitted the pact for ratification or written federal regulations.").

193 Id.

194 Id.

195 Id. 
and the steps necessary to keep global warming below two degrees Celsius, the internationally agreed-upon goal, a group of researchers issued a report road map. ${ }^{196}$ This would entail "a rapid transformation of the world's energy system (measures such as banning the sales of gasoline vehicles in many cities within a decade) that went far beyond many of the proposals made in [the] California [September 2018 meeting]." 197

Even so, California Governor Brown has met with China's chief climate negotiator and "announced plans for California and China to work together on zero-emissions vehicles and fuel-cell research[,]" and "several blue-state governors met behind closed doors with the environment ministers of Canada and Mexico to forge new partnerships on issues like electric vehicles and curbing emissions of methane." 198 While it is unusual for American governors to, in effect, take the lead on international climate diplomacy, Canada's minister of environment and climate change notes, "It is important to show the world that we're still working with U.S. states," and that " $\mathrm{t}]$ here really are practical things we can do together." 199

\section{Iterative Federalism and Climate Change}

While the potential for federal action in support of climate change mitigation appears slim in the near-term, state and local governments (as well as regional alliances of states) have a long history of involvement in addressing climate change and in catalyzing the federal government to act-through the dynamic of "iterative federalism." 200 By incentivizing other levels of government to act, "iterative federalism" can act as a mechanism for tipping norms and addressing the market failures. However, what is worrisome in the present moment is whether federalism doctrines, such as preemption, might be used to prevent subnational governments from playing a leadership role in climate change. This Subsection examines two examples of subnational

\footnotetext{
196 Id.

197 Id.

198 Id.

$199 \mathrm{Id}$.

200 Carlson, supra note 106.
} 
participation-indeed leadership-in climate change mitigation as a way of illustrating the power of iterative federalism. This illustration also serves as a warning of what may be lost if the federal government fails to act, or worse, preempts subnational climate change policy, by, for example, withdrawing the California waiver on auto emissions.

The California example, in particular, also serves to illustrate the point made by Professor Hale in the global context about how climate change is not only a tragedy of the commons but also a tipping problem. As noted above, in tipping problems, the primary obstacle to cooperation is less the threat of free-riding than the absence of incentive to act in the first place. ${ }^{201}$ My discussion here will adapt Hale's theory and apply it to the domestic context in considering federalism and environmental law through the two brief examples outlined in this Subsection.

As these examples demonstrate, the most productive approaches to environmental regulation domestically have involved cooperative federalism. As Professor Carlson notes:

[A]ccounts of state involvement on climate change [that] emphasiz[e] how the states have partly filled the regulatory voids created by federal inaction [] misses the important-indeed criticalbackdrop of the federal government and federal law. The most innovative state responses to climate change are neither the product of state regulation alone nor are they exclusively the result of federal action. Instead, such regulations are the results of repeated, sustained, and dynamic lawmaking efforts involving both levels of government-what I term "iterative federalism." 202

The following two examples illustrate this point:

Motor Vehicle Emissions Standards (the California example): Policy reducing auto emissions has toggled back and forth, primarily between California and the federal government through multiple iterations, with each level of government spurring on the other (vertically) and with California's example paving the way for other states (horizontally).203

201 Hale, supra note 111, at 2-3.

202 Carlson, supra note 106, at 1099.

$203 I d$. at 1107-09, 1128 ("California has led the way in pushing increasingly strict mobile source emissions standards.”). 
Because of the problems of traffic and smog in the Los Angeles area, California had an incentive to act in ways that few other states did.204

Several environmental law scholars analyze the need for a strong federal role through the framework of the tragedy of the commons problem. ${ }^{205}$ Indeed, there is a history of states opting for lax environmental regulation and externalizing the effect of this weak regulation. 206 This is particularly true with cars. Because they are mobile and there is, by definition, a national market for them, states have an incentive to externalize the problem of auto emissions beyond the state of manufacture. ${ }^{207}$ However, we might also observe the failure of states to reduce auto emissions in cars that are manufactured there as a tipping problem, where few states had an incentive to act in the first place. Given that states, such as California in the automobile context (and Gulf states in the context of rising sea levels and the problem of flooding), are affected by climate change in disparate ways, certain states in fact do have incentives to be first movers in particular contexts.

In the area of reducing auto emissions, California paved the way, initially through legislation in 1960,208 which laid the groundwork for Congress to adopt the Clean Air Act in 1963.209 As of September 2018, twelve states and the District of Columbia were following California's auto emission standards, 210 as other states are permitted to do under the federal Clean Air Act.211 California's requirements include one specifying that auto manufacturers "generate a certain number of Zero Emission Vehicle [] credits, depending upon the number of vehicles produced and delivered within the state." 212

\footnotetext{
204 Id. at 1110.

205 Hale, supra note 111, at 1.

206 Carlson, supra note 106, at 1099 (noting "the free rider incentives are large" regarding carbon emissions).

207 Id. at 1139 (discussing how the fact that cars are part of a national market supports the argument for federal regulation).

$208 \mathrm{Id}$. at 1110.

209 Clean Air Act of 1963, Pub. L. No. 88-206, 77 Stat. 392 (codified as amended at 42 U.S.C. $\$ \$ 7401-31$ et seq. (2018)).

210 Barboza, supra note 162.

211 Engel, supra note 19, at 68-69.

$212 I d$. at 69.
} 
In the past, Congress has passed legislation to preempt other states from adopting "any standard relating to the control of emissions from new motor vehicles," but exempted California. ${ }^{213}$ Through this dynamic, the federal government has quasi-deputized California as a "superregulator," wherein other states could choose to follow the federal or the California standard.214 Because California has the largest automobile market in the country, many states and manufacturers opt to follow the California (more stringent) standard.215 While the Obama administration provided a waiver for California's progressively more stringent auto emission standards, as discussed in Section II.A.5, supra, the Trump administration threat to rescind the waiver and issue its own standards would, in effect, end the ability of states (such as California) to continue the progress in reducing auto emissions. ${ }^{216}$

Cap-and-Trade Schemes: While the first mover with the auto emission standards was California, states have not necessarily always been the first to act in iterative federalism schemes. ${ }^{217}$ The first cap-andtrade scheme was established by Congress when it enacted the Acid Rain Program in 1990 to reduce GHGs emitted from power plants. 218 This set the stage for the creation of a regional group, the Ozone Transport Commission (OTC), which was established as part of the Clean Air Act amendments of 1990. The OTC was designed to prod northeastern states to combat ozone pollution on a regional basis and established a regional cap-and-trade program. ${ }^{219}$ While the OTC was

213 Clean Air Act, 42 U.S.C. $\$ 7543(a),(b)(1)$ (2018). See also Carlson, supra note 106, at 1111.

214 Carlson, supra note 106, at 1100, 1107.

215 Id. at 1141 (referring to California and explaining that by giving California a waiver to set a higher standard in reducing auto emissions, the federal government was "granting the state with the largest market share of automobiles in the country the ability to set more stringent standards and thus serve as a single laboratory of democracy"); see also id. at 1124 (discussing how over time, many other states chose to follow California); Barboza, supra note 162 (explaining that the California standard is followed by a dozen other countries and the District of Columbia).

216 Carlson, supra note 153, at 2.

217 Carlson, supra note 106, at 1141.

21842 U.S.C. $\$ \$ 7651-61 f(2016)$.

219 Carlson, supra note 106, at 1145 (noting that "these same states had already started to work cooperatively in the 1980 s to coordinate efforts to combat acid rain. By the time the OTC was established, many environmental officials from these states already had cooperative working relationships"). Carlson notes, "Sources that reduce their emissions below their 
successful in reducing GHG emissions, downwind northeast states continued to experience significant cross-border pollution not from fellow OTC members, but from upwind states in the Midwest and Southeast.220 To address this more widespread regional problem, the EPA expanded the OTC cap-and-trade program to a broader array of states. The current iteration is the Regional Greenhouse Gas Initiative. 221

How Norm Cascades Occur and Other Lessons Learned: To understand why policy has bounced back and forth between federal and sub-federal governments in these case studies of climate change mitigation, it is useful to consider the notion of "norm cascades" developed by IR scholars, who use the tipping problem idea to theorize how norms tip and diffuse regionally and globally.222 Applying the notion of norm cascades to climate change mitigation yields a better understanding of why states (and the federal government) adopt the policies they do. For example, "regulation at the state and local level can prompt burdened interest groups to appeal to higher jurisdictional regulators for relief from the costs of inconsistent lower-level regulation." 223

The auto emissions example poses lessons that highlight the value of allowing first movers to assist with tipping a norm, in contrast to a pure preference for either nationalization or decentralization. Along these lines, Richard Revesz has argued that devolution of environmental policymaking to the states can assist more in producing socially optimal levels of regulation, based on competition rather than centralized policymaking. 224 As a laboratory of experimentation, California was able to take on the risks (and enjoy the benefits) of innovation. In some instances, California made some costly misjudgments in the direction of

allowances may trade, sell, or bank the excess, while sources that exceed their emissions allowances are subject to hefty financial penalties." Id. at 1144.

220 Id. at 1149 .

221 Id. at $1149-52$.

222 Martha Finnemore \& Kathryn Sikkink, International Norm Dynamics and Political Change, 52 INT'L ORG. 887 (1998).

223 Engel, supra note 19, at 71 (describing this in the context of a related concept she describes as a "domino effect").

224 Richard L. Revesz, Rehabilitating Interstate Competition: Rethinking the "Race to the Bottom” Rationale for Federal Environmental Regulation, 67 N.Y.U. L. REV. 1210 (1992). 
both over- and under-regulation (due in part to imperfect information and scientific uncertainty).225 But by allowing California to experiment, these missteps were limited to one jurisdiction, providing opportunities for learning and improvement as policy innovation was taken up at the federal level.

As the experience of California also suggests, while wholesale devolution was not necessary, allowing California to be at least one laboratory of experimentation avoids the type of "race to the bottom" and other problems that concern proponents of nationalization. ${ }^{226}$ Perceptively, Professor Carlson observes that iterative federalism arrangements "reject a central assumption among virtually all federalism theories[, which presume] that states are to be treated as a single analytic unit." 227 Indeed, in the case of auto emissions, it was only a single jurisdiction (i.e., California) that was designated as a "superregulator." In the cap-and-trade case, a single regional body had authority. 228 Both cases involved the blessing of the federal government, but not without some degree of contestation and negotiation. The iterative effect of policy shifting back and forth between federal and subfederal actors helped catalyze and tip the norm to wider acceptance in both case studies.

While there are clear benefits of incentivizing first movers at the state and local level, there are also solid economic arguments in favor of national preemption in an inherently national market, such as in the automobile sector, under circumstances where the federal government is committed to addressing information asymmetries and the problem of special interests who seek to externalize the negative effects of their own environmentally unfriendly behavior. For one, the federal government often has "superior resources and the ability to conduct more sophisticated, coordinated research and development." 229 Second, there can be a significant value in capturing efficiencies of scale when manufacturers only have to follow one national standard in producing

\footnotetext{
225 Carlson, supra note 106, at 1137-38.

226 Id. at 1138.

227 Id. at 1107. Cf. Gerken, supra note 22, at 1720 ("For all intents and purposes, however, there aren't fifty independent laboratories these days; there are two. One is red, one is blue[.]").

228 Carlson, supra note 106, at 1107.

229 Id. at 1104.
} 
the same product for consumers in all fifty states.230 Third, national regulation is useful because in the auto market, states (and manufacturers) can cost externalize-and avoid internalizing the costs of regulation. ${ }^{231}$ As Rick Hills has observed, "Cars are not manufactured in California, so California's politicians can safely urge tough standards, knowing that the costs will be borne by out-of-state businesses, their employees, and their shareholders." 232

The cap-and-trade example also highlights the value of the federal government's role where interstate externalities make it less likely for any particular state (or group of states) to be a first mover. ${ }^{233}$ Moreover, federal law "may reinforce or strengthen voter preferences within a particular state or region for environmental change[,]" where otherwise voters (or interest groups, such as business or other lobbyists) may prefer more lax standards, precipitating a race to the bottom. 234

However, the federal government today has signaled hostility, rather than an inclination to address the problem of externalizing negative effects, much less the information asymmetries inherent in the highly technical field of climate science. Thus, first movers, such as California and others, will need to continue to exercise leadership, incentivized by their own pragmatic or even ideational motives, to tip the climate change mitigation norm in a direction that will not only secure compliance with the Paris Agreement, but more importantly, will also help address the negative effects of climate change.

In sum, the initiative of state and local governments (and regional alliances) in addressing environmental protection concerns, such as climate change, is critical. This is particularly true where the federal government is not committed to addressing market failures-and

230 Id. at $1138-40$.

231 Id. at 1140.

232 See Roderick M. Hills, Jr., Against Preemption: How Federalism Can Improve the National Legislative Process, 82 N.Y.U. L. REV. 1, 23 n.74 (2007). Robert Cooter and Neil Siegel advance a similar point in positing the idea "collective action federalism" to suggest that Congress has some authority to regulate "noncommercial harms that spill over state boundaries, such as certain environmental problems," where, otherwise, under the Commerce Clause, Congress is restricted to only regulating commercial activity. Robert D. Cooter \& Neil S. Siegel, Collective Action Federalism: A General Theory of Article I, Section 8, 63 STAN. L. REV. 115, 119-20 (2010).

233 Carlson, supra note 106, at 1154.

234 Id. at 1158. 
instead seems intent on reinforcing them. Certainly, the federal government has a potentially important coordination role to play (given the advantages discussed above). But, in the meantime, the leadership of sub-federal government actors can build support for climate change policy at the national level.

\section{Applying Lessons from Global Governance to Federalism}

This Section extracts the lessons gleaned from global environmental governance and IR scholarship to further clarify how sub-federal governments can address the political market failures that are apparent in climate policy. To recap, these failures include (1) lack of information due to the subversion of science, knowledge, and information, as well as (2) the regulatory capture of climate policy by powerful minority economic interests, who are determined to externalize the costs of their climate unfriendly behavior. While today, the federal government stands by (or, worse, reinforces these failures), it is up to sub-federal governments to address these challenges and to set the stage for an eventual shift to new climate policy at the federal level.

In considering the diffusion of policies aimed at mitigating climate change, it is tempting to view the norm cascade sweeping through at least some state and local jurisdictions as motivated by a common purpose. Under the standard tragedy of the commons analysis, we may assume that all jurisdictions have similar, if not identical, motives. 235 However, in order to explain the fact that certain jurisdictions have been first and more aggressive movers in reducing greenhouse gas emissions, it is apparent that some actors-such as California-have different interests and motives.

As Hale explains, certain mitigation steps taken by particular jurisdictions may not even be viewed as primarily climate policy per se: 236

[Rather,] [m]any [] "co-benefits" may come along with specific mitigation actions, including reducing local air pollution and improving human health, increasing energy security and reliability,

235 Hale, supra note 111 , at 16.

236 Id. 
developing new industrial sectors, preserving forests, [reducing traffic,] etc. In some cases, these co-benefits temper the cost of mitigation actions; in other cases, the other benefits are governments' primary focus, and mitigation is an ancillary result. 237

Even where there are net costs to climate regulation, there may be other incentives or ideational preferences-such as the value of upholding a "green" policy (as is certainly the case with particular corporate actors and even public pension funds who operate under stated ethical or other requirements). ${ }^{238}$

Further, while the economic literature on climate change often assigns a discount rate to future benefits of climate mitigationassigning a lower value to the benefit realized in the future than the cost born now-this reasoning can be misleading once we, again, consider that today's jurisdictions are not necessarily similarly situated. For example, "[f]or small island states, arid countries near the equator, and coastal cities, the impacts are already severe and will become existential." 239

For these reasons, it makes sense to assess climate policy not only within the framework of the standard tragedy of the commons analysis, but also to recognize that climate policy involves a "tipping point structure." 240 By viewing climate policy as a tipping problem, we can view the Paris climate process as a "catalytic" institutional process that assists states, sub-state, and non-state actors in cooperating to shift actors' propensity to take steps over time and to progressively intensify the level or commitment and steps taken, as they learn-by-doing and generate increasing returns. ${ }^{241}$

\footnotetext{
237 Id.

$238 \mathrm{Id}$.

239 Id. at 17.

$240 \mathrm{Id}$. at $2-3$.

241 Id. at 22. Hale discusses elements of the catalytic approach, which he indicates includes measures that: (1) shape future expectations and aspirations; (2) stimulate first-movers and incremental action through flexibility; (3) are an iteration of commitments; (4) and increase the effect of prior action on subsequent action (through (a) material transfers to alter future preferences and capacities; (b) transferring experiences to shape the informational environment; (c) normative benchmarking; and (d) domestic constituency-building). Id.
} 


\section{SANCTUARY JURISDICTIONS}

In this Part, I identify how sanctuary jurisdiction policies represent a merger of local and global concerns in a way that addresses John Hart Ely's insight about underrepresentation of minority rights as a political market failure. To provide a contrast with the climate policy case study above, Section III.A provides background by discussing the international law framework concerning immigrants. Section III.B then turns to an examination of the rise of sanctuary jurisdictions within the United States as a response to federal immigration and refugee policies. Section III.C provides a typology of today's sanctuary policies aimed at disentanglement from the federal immigration enforcement apparatus. In examining what motivates these policies, Section III.C also reflects on the extent to which these sub-federal initiatives address the problem of minority underrepresentation. Section III.D revisits the notion of norm cascades and tipping problems, discussed supra (in Part II on climate policy), to examine how state and local sanctuary policies may assist in tipping norms concerning the treatment of immigrants in one direction or another.

Tipping the norm of fair treatment could help address the fact that the political process has failed to protect the rights and dignity of humans who, despite their formal lack of status as citizens, are entitled to respect, simplify by virtue of our shared humanity (as international human rights law asserts, grounded in Immanuel Kant's notion of human dignity).242 However, conversely, given Trump's efforts to encourage states, counties, and localities to cooperate with his draconian deportation policies, ${ }^{243}$ the norm could also tip in the direction of stigmatizing immigrants further. But adapting Ely's concern regarding the minority underrepresentation problem as a failure of democracy, my normative approach is to argue that sub-federal governments should safeguard equality and dignity of immigrants, if for no other reason than

\footnotetext{
242 ImManuel Kant, Foundations of Metaphysics of Morals 49 (Lewis W. Beck trans., 1 st ed. 1959). Kant's theory of human dignity provides an important theoretical underpinning for the contemporary human rights idea, as he claimed that "rational beings are designated 'persons' because their nature indicates that they are ends in themselves, i.e., things which may not be used merely as means." Id. at 46 .

243 For further discussion, see infra Section III.B.
} 
to strengthen a relationship of trust with immigrant communities and to advance local goals concerning fairness, thereby enhancing the efficacy of criminal justice and other policies. Such local concerns are well within the authority of states, counties, and localities-quite separate and apart from the federal government's immigration authority $244-$ as demonstrated in my discussion of federalism doctrine below.

\section{A. Shortcomings of the International Framework on Immigrants}

This Section provides background by discussing the dearth of international law protections for immigrants. I examine how, despite international law's aspiration to address both collective action failures and minority rights, in reality, the international framework concerning immigrants is weak to nonexistent.

As mentioned in the Introduction to this Article, while both climate and sanctuary policies address inherently transnational concerns, the climate change case study (discussed supra) indicates greater potential for international cooperation because of the Paris architecture. In contrast, sanctuary jurisdictions today do not, by and large, look to international agreements or norms as a reference point for protective policies toward immigrants (though, as discussed infra, earlier sanctuary policy did).

While immigration is an inherently transnational matter, international standards protecting immigrants are sparse and in many cases nonbinding. Despite the existence of elaborate international rules concerning the movement of goods and trade more broadly, there is a dearth of international law on the movement of people. 245

As discussed in Parts I and II, international law is a regime created by nation-states. Rather than the traditional view of the nation-state as a "black box," contemporary international law and IR scholars analyze the positions that countries take on the international stage as reflecting political preferences of those who wield power domestically in these

244 Clare Huntington, The Constitutional Dimension of Immigration Federalism, 61 VAND. L. REV. 787 (2008).

245 For discussion of this asymmetry, see, for example, THOMAS, supra note 53. 
various nations. 246 As nation-states reflect these preferences, it may sometimes be in the interest of their governments to agree to certain international standards regarding trade; however, in immigration matters, it is in the interest of powerful nations (who are the receiving countries for immigrants) to address transnational concerns on immigrants through bi-lateral agreement, diplomacy, or other discrete mechanisms. 247

Thus, while political refugees are protected under the Refugee Convention and Protocol,248 there are few international legal protections for so-called economic migrants. To help close this gap, the Global Compact for Safe, Orderly, and Regular Migration (Global Compact on Migration) was adopted in December 2018.249 The aim for the Global Compact is to promote international cooperation on migration issues; however, the United States rejected it.250 In any event, it is non-binding.

Broadly speaking, some sanctuary jurisdictions justify policies based on norms that are protected in international human rights law contained in binding treaties, which include commitments related to equality, inclusive communities, racial profiling, due process, fairness, and human dignity. ${ }^{251}$ However, state and local officials are not citing to

246 Putnam, supra note 29 (recognizing that national-level policymakers in international negotiations face constituencies at both domestic and international levels and exploring the intertwining of the two).

247 Jennifer Gordon, People Are Not Bananas: How Immigration Differs from Trade, 104 NW. U. L. REV. 1109, 1139-42 (2010). It is possible that the absence of strong international law protecting immigrants may itself reflect a collective action problem. But, alternatively, it may represent a conscious decision by states to preserve their longstanding discretion to exclude non-nationals (as Gordon's work suggests).

248 Convention Relating to the Status of Refugees, July 28, 1951, 19 U.S.T. 6259, 189 U.N.T.S. 137; Protocol Relating to the Status of Refugees, Jan. 31, 1967, 19 U.S.T. 6223, 606 U.N.T.S. 267. The United States is a party to the Refugee Protocol. Id.

249 Nick Cumming-Bruce, U.N. Approves Sweeping Deal on Migration, But Without U.S. Support, N.Y. TiMES (Dec. 10, 2018), https://www.nytimes.com/2018/12/10/world/europe/unmigration-deal-morocco.html [https://perma.cc/M9W6-SJEB].

250 Press Release, U.S. Mission to the United Nations, National Statement of the United States of America on the Adoption of the Global Compact for Safe, Orderly, and Regular Migration (Dec. 7, 2018), https://usun.state.gov/remarks/8841 [https://perma.cc/9HW2EXVG].

251 See, e.g., ICCPR, supra note 42, art. 2; id. art. 26 (on equality norms); id. art. 23 (on family rights); G.A. Res. 217 (III) A, art. 1, Universal Declaration of Human Rights (Dec. 10, 1948) (on dignity) [hereinafter UDHR]. Note that the United States is a party to the ICCPR. While the UDHR is non-binding, it has been adopted by nearly every country, and the United 
nor rallying around international standards the way mayors and governors have explicitly done in the climate change context, particularly in the aftermath of the President's Paris accord withdrawal announcement.

\section{B. Four Waves of "Sanctuary" Policies}

This Section explores the emergence of subnational sanctuary jurisdictions. As mentioned, unlike the climate policy context, subfederal policy innovators in the sanctuary context have largely not rallied around international norms per se (with the exception of the first wave of sanctuary policies during the 1980s, discussed directly below). Yet even from their initial emergence, many sanctuary policies aim to address norms embodied in international standards regarding fair treatment and the rights of minorities. Immigrants in the United States are, as a group, a minority that is, essentially by definition, underrepresented in the political process. ${ }^{252}$

The term "sanctuary jurisdiction" is itself somewhat of a misnomer today, in the sense that it now applies to a range of jurisdictions motivated by a variety of concerns beyond the original ones that prompted the initial wave of sanctuary policies, which were aimed at providing sanctuary from deportation. ${ }^{253}$ Sanctuary policies in recent U.S. history have proceeded in four successive waves, each oriented in varying degrees to address the problem of minority underrepresentation of immigrants. 254

First, sanctuary policies originally grew out of both a churchcentered movement as well as a concern by local law enforcement regarding the influx of Central American refugees who fled civil wars in

States played a leadership role in its development, with Eleanor Roosevelt as chair of the U.N. committee that drafted it. GLENDON, supra note 57.

252 See discussion supra Part I regarding how undocumented immigrants are largely denied the right to vote or ability to run for federal office.

253 Fact Sheet: Understanding Trust Acts, Community Policing, and "Sanctuary Cities", AM. IMMIGR. COUNCIL (Oct. 10, 2015), https://www.americanimmigrationcouncil.org/research/ sanctuary-cities-trust-acts-and-community-policing-explained\#.WHXPfy6tdDc.email [https:// perma.cc/CDB4-QRV3].

254 The framework for the four waves of policies is introduced and discussed more thoroughly in Lai \& Lasch, supra note 106, at 546-48. 
the 1980s but were denied asylum in the United States. Churches, synagogues, and other religious institutions came together to oppose the repatriation of refugees to the countries they had fled because they feared persecution. This movement became known as the Sanctuary Movement. At its height, over 150 congregations publicly defied the federal government, openly sponsoring and supporting undocumented refugee families, largely from El Salvador and Guatemala. 255

Sanctuary cities sprung up during this period as well, out of concern for what was perceived as the federal government's lack of compliance with international law, based on the U.S. government's rejection of refugee applications from Central Americans. ${ }^{256}$ In some cases, these cities referred to international human rights standards concerning the treatment of refugees. For example, the city of Davis, California adopted a resolution declaring that "the citizens of Davis are concerned about violations of human rights throughout the world." 257 The Davis resolution also invoked the fact that in enacting the Refugee Act of 1980, Congress had adopted the definition of "refugee" found in the U.N. Convention Relating to the Status of Refugees. ${ }^{258}$ Further, the Davis resolution mentioned that the U.N. High Commission on Refugees had "recognized that persons fleeing El Salvador and Guatemala are bona fide political refugees, yet fewer than two percent are being granted that status by the U.S. Immigration and

255 Catherine Powell, The United Divided States: San Francisco Sues Donald Trump for Sanctuary Cities Order, JUST SECURITY (Feb. 13, 2017), https://www.justsecurity.org/37589/ united-divided-states-san-francisco-sues-donald-trump-sanctuary-cities-order [https:// perma.cc/L8MH-FYNZ].

256 See Rose Cuison Villazor, What Is a "Sanctuary"?, 61 SMU L. REV. 133, 142-43 (2008) (discussing that in the 1980s, municipalities-which we now refer to as "sanctuary cities"adopted non-cooperation policies alongside churches that provided safe havens to Central American migrants).

257 Davis, Cal., Res. 5407 (Mar. 5, 1986). While the resolution has been updated, the most recent one incorporates the original resolution (containing the references to human rights and refugee law) by reference. Mayor Daniel M. Wolk, Resolution No. 14-153, Series 2014: Resolution Reaffirming and Promoting Davis as a City of Sanctuary (Nov. 5, 2014), http:// documents.cityofdavis.org/Media/Default/Documents/PDF/CMO/Sanctuary-City/Resolution14-153-Reaffirming-Davis\%20-as-a-Sanctuary-City.pdf [https://perma.cc/7E99-U5R9].

258 Id. For analysis of how the Refugee Act of 1980 incorporates the definition of refugee found in the U.N. Convention Relating to the Status of Refugees, see Joan Fitzpatrick, The International Dimension of U.S. Refugee Law, 15 BERKELEY J. INT'L L. 1 (1997). 
Naturalization Service." 259 Before being updated in recent years, the original sanctuary ordinance in San Francisco also referred to human rights violations in El Salvador, as well as the responsibility of the United States to political refugees fleeing El Salvador and Guatemala. ${ }^{260}$

Along with the rise of these early sanctuary cities, the religious activists in the church-centered movement drew upon the emerging use of international human rights norms by U.S. advocates more broadly, invoking the principles of personal accountability developed in the Nuremburg tribunals, to justify what the federal government considered alien smuggling. Others in the Sanctuary Movement referred to it as a new "Underground Railroad," drawing on religious and moral principles of the nineteenth century U.S. abolitionist movement and building off of the experience of the 1960s with civil disobedience campaigns against racial segregation. Some activists paid a price for this advocacy, with the Reagan Justice Department criminally prosecuting a small handful of the activists in the Sanctuary Movement. ${ }^{261}$

The second wave of sanctuary policies, however, was more directly related to the emergence of the crim-immigration regime and "federal pressure on local jurisdictions to participate in immigration enforcement," 262 which have blurred the lines of federal and state authority. While immigration law is a federal matter, ${ }^{263}$ criminal law has traditionally been viewed as falling within the realm of state and local law. ${ }^{264}$ As Annie Lai and Christopher Lasch explain, "the second wave of

259 Res. 5407, supra note 257, at 1.

260 For San Francisco's original "City and County of Refuge" Ordinance, see S.F., Cal., Ordinance 375-89 (Oct. 16, 1989), http://citizenrobo.org/statute/4050/attachment/272 [https:// perma.cc/6SV5-WJG5]. For further background, see Sanctuary City Ordinance, OfF. CIVIC ENGAGEMENT \& IMMIGRANT AFF., CITY \& COUNTY S.F., https://sfgov.org/oceia/sanctuary-cityordinance-0 [https://perma.cc/J4CA-XVBX] (last visited Apr. 14, 2019).

261 Susan Gzesh, Central Americans and Asylum Policy in the Reagan Era, MigRATION POL'Y INST. (Apr. 1, 2006) https://www.migrationpolicy.org/article/central-americans-and-asylumpolicy-reagan-era [https://perma.cc/YU5F-LAB9].

262 Lai \& Lasch, supra note 106, at 545-46. While some scholars use the term "crimmigration," I am using the term "crim-immigration" to emphasize the contestation between local criminal law and federal immigration enforcement. For a thoughtful discussion of efforts to merge criminal law and immigration law-and efforts to resist this merger-see $i d$.

263 See discussion supra Section I.D.

264 See United States v. Morrison, 529 U.S. 598, 601-06, 618 (2000) (striking down the civil remedy in the Violence Against Women Act and finding that " $[t]$ he regulation and punishment of intrastate violence... has always been the province of the States.”); United States v. Lopez, 
sanctuary policies followed [federal] legislation in the 1990s and a legal opinion from the Office of Legal Counsel after September 11th that sanctioned arrests by local law enforcement for violations of civil immigration laws." 265 In response, sanctuary policies, enacted in the decade following the September 11th attacks, "challenged the federal government's... assertion of cooperative immigration enforcement as essential to domestic security." 266

The third wave of policies was prompted by resistance to the "Secure Communities" program, initiated under President George W. Bush, and continued under President Barack Obama. This wave of resistance "likewise arose as a response to federal pressure on local law enforcement to participate in immigration enforcement...."267 Secure Communities created a system whereby the biometric fingerprint data of every person booked into a local jail whose fingerprints are run through the Federal Bureau of Information National Crime Information Center database and automatically shared with federal immigration officials. After the number of deportations hit record numbers, leading to severe criticism of President Obama, his administration ended Secure Communities. 268

The fourth wave of policies was triggered by the campaign and election of Donald Trump. During his campaign for President, candidate Trump ran on a nativist platform, claiming he would "Make America [G]reat [A]gain." $269 \mathrm{He}$ described Mexican immigrants as rapists and drug dealers, saying, "[t]hey're bringing drugs. They're bringing crime. They're rapists." 270 Thus, he promised to build a wall on

\footnotetext{
514 U.S. 549, 567 (1995) (referring to the prohibition on guns in school zones as "a general police power of the sort retained by the States").

265 Lai \& Lasch, supra note 106, at 546.

266 Trevor George Gardner, The Promise and Peril of the Anti-Commandeering Rule in the Homeland Security Era: Immigrant Sanctuary as an Illustrative Case, 34 ST. LOUIS U. PUB. L. REV. 313, 315, 324 (2015) (describing "second wave" of sanctuary policies from 2001-2008).

267 Lai \& Lasch, supra note 106, at 546-47.

$268 \mathrm{Id}$. at $547-48$.

269 Kelly J. Baker, Make America White Again?, ATLANTIC (Mar. 12, 2016), https:// www.theatlantic.com/politics/archive/2016/03/donald-trump-kkk/473190 [https://perma.cc/ 2LXV-MRSV].

270 Donald Trump Transcript: 'Our Country Needs a Truly Great Leader', WALL STREET J. (June 16, 2015, 2:29 PM), https://blogs.wsj.com/washwire/2015/06/16/donald-trumptranscript-our-country-needs-a-truly-great-leader.
} 
the southern border of the United States as a centerpiece of this campaign. ${ }^{271}$ In addition to expressing a desire to ban Muslims from the United States, ${ }^{272}$ once elected, within days of taking office, Trump issued a series of executive orders barring visitors mainly from predominantly Muslim countries. ${ }^{273}$ He reportedly referred to African countries and Haiti as "sh-thole" countries and indicated, by contrast, a preference for visitors from Norway. ${ }^{274}$ Trump also granted a presidential pardon to Sheriff Joe Arpaio,275 who was convicted for contempt of court for "repeatedly and knowingly disobey[ing a federal judge's] orders to cease policing tactics against Latinos that [the judge ruled] amount to systemic racial profiling," in the context of what Arpaio claimed was a crack-down on undocumented immigration. 276

On sanctuary jurisdictions specifically, as both a candidate and now as President, Trump has promoted the notion that sanctuary jurisdictions generate and protect immigrant crime. ${ }^{277} \mathrm{He}$ has promoted

271 Amber Phillips, The First Brick Hasn't Been Set and Trump's Border Wall Is Already Going South on Him, WASH. POST (Apr. 24, 2017), https://www.washingtonpost.com/news/thefix/wp/2017/04/24/4-reasons-trumps-border-wall-is-already-going-south-on-him/?utm_term=. d597b8cf5a35 [https://perma.cc/NCA2-YDYX].

272 Jeremy Diamond, Trump's Latest Executive Order: Banning People from 7 Countries and More, CNN (Jan. 29, 2017, 4:38 PM), https://www.cnn.com/2017/01/27/politics/donald-trumprefugees-executive-order/index.html [https://perma.cc/QV85-PP5Z].

273 Id.

274 "Sh*thole Countries" Respond to Trump's Rhetoric, CBS NEWs (Jan. 12, 2018, 10:29 AM), https://www.cbsnews.com/news/donald-trump-shthole-countries-response-from-haiti-africael-salvador [https://perma.cc/6ZPZ-E9ZP].

275 Julie Hirschfeld Davis \& Maggie Haberman, Trump Pardons Joe Arpaio, Who Became Face of Crackdown on Illegal Immigration, N.Y. TIMES (Aug. 25, 2017), https:// www.nytimes.com/2017/08/25/us/politics/joe-arpaio-trump-pardon-sheriff-arizona.html [https://perma.cc/S8GQ-7UMW].

276 Merrit Kennedy, In Racial Profiling Lawsuit, Ariz. Judge Rules Sheriff Arpaio in Contempt of Court, NPR (May 14, 2016, 11:22 AM), https://www.npr.org/sections/thetwo-way/2016/05/ 14/478050934/in-racial-profiling-lawsuit-ariz-judge-rules-sheriff-arpaio-in-contempt-of-court [https://perma.cc/QNN9-DX42]; see also Colin Dwyer, Ex-Sheriff Joe Arpaio Convicted of Criminal Contempt, NPR (July 31, 2017, 4:08 PM), https://www.npr.org/sections/thetwo-way/ 2017/07/31/540629884/ex-sheriff-joe-arpaio-convicted-of-criminal-contempt [https:// perma.cc/3W6K-8652].

277 For example, Trump has prominently pointed to the killing of Kathryn Steinle in San Francisco by an undocumented immigrant, who was ultimately acquitted of murder. Daniel Arkin, Kathryn Steinle Shooting: Politics Aside, Experts Say Verdict Based on Reasonable Doubt, NBC NEws (Dec. 1, 2017, 4:03 PM), https://www.nbcnews.com/news/us-news/kathryn-steinleshooting-politics-aside-experts-say-verdict-based-reasonable-n825731 [https://perma.cc/XZ33- 
misleading claims linking sanctuary jurisdictions and crime, by relying "on a rhetoric of immigrant criminality to support his harsh immigration enforcement" and by characterizing sanctuary jurisdictions "as dangerous and harmful." 278 However, evidence indicates that immigrants, including undocumented immigrants, are less likely to commit crime than native-born U.S. citizens. ${ }^{279}$

Fulfilling a campaign promise to "cancel all federal funding to sanctuary cities," 280 President Trump issued his so-called sanctuary jurisdictions executive order-entitled "Enhancing Public Safety in the Interior of the United States" 281 on January 25, 2017, shortly after he came into office. Section 9(a) of the Order threatens to withhold unspecified federal funding to jurisdictions that "willfully refuse to comply with 8 U.S.C. 1373." 282 Subsection 1373(a) provides that a "local government entity or official may not prohibit, or in any way restrict, any government entity or official from sending to, or receiving from, [federal immigration officials] information regarding the citizenship or

UUNG]. The defendant, Jose Ines Garcia Zarate, had been deported five times (but returned to the United States). Id. He was acquitted of the most serious charges-first-degree murder, second-degree murder, and involuntary manslaughter, likely because of the presence of reasonable doubt-but was found guilty of illegal possession of a firearm. Id.

278 Lasch et al., supra note 7.

279 Note a 2017 report by the Cato Institute, stating, "All immigrants are less likely to be incarcerated than natives relative to their shares of the population. Even illegal immigrants are less likely to be incarcerated than native-born Americans." Michelangelo Landgrave \& Alex Nowrasteh, Criminal Immigrants: Their Numbers, Demographics, and Countries of Origin, CATO INST. (Mar. 15, 2017), https://www.cato.org/publications/immigration-reformbulletin/criminal-immigrants-their-numbers-demographics-countries\#full [https://perma.cc/ S6QS-PFMS]. See also Salvador Rizzo, Trump's Claim That Immigrants Bring 'Tremendous Crime' Is Still Wrong, WASH. POST (Jan. 18, 2018), https://www.washingtonpost.com/news/factchecker/wp/2018/01/18/trumps-claim-that-immigrants-bring-tremendous-crime-is-still-

wrong/?utm_term=.d0c678f6b74d [https://perma.cc/9JBW-KP6L] (giving Trump's claims four Pinocchios, which denotes an entirely false statement, and noting that "the violent crime rate was cut nearly by half during a period in which unauthorized immigrants tripled"). For an explanation of the Washington Post's Pinocchio scale, see Glenn Kessler, About the Fact Checker, WASH. POST (Jan. 1, 2017), https://www.washingtonpost.com/politics/2019/01/07/ about-fact-checker/?utm_term=.d42c25d1792f [https://perma.cc/2UNN-H6JK].

280 Donald J. Trump, Donald Trump's Contract With the American Voter (2016), https://assets.donaldjtrump.com/_landings/contract/O-TRU-102316-Contractv02.pdf [https:// perma.cc/VBF9-AFF9].

281 Exec. Order No. 13768, 82 Fed. Reg. 8799 (Jan. 25, 2017).

282 Id. 
immigration status... of any individual." 283 Although Trump's definition of "sanctuary city" has is hardly a model of precision, the Executive Order defines a "sanctuary jurisdiction" as one "that willfully refuse[s] to comply with 8 U.S.C. 1373." 284

San Francisco-which Trump has singled out for criticism and which was involved in the earliest challenge to Trump's sanctuary jurisdictions executive order-initially became a sanctuary city in 1989 in response to the Central American refugee crisis, but the goals behind its sanctuary city status today are far broader. The city's Administrative Code Chapter 12H.1 "affirms that the City and County of San Francisco is a City and County of Refuge." "Additionally, Chapter 12I of the San Francisco Administrative Code emphasizes the importance of fostering 'respect between law enforcement and residents' in particular 'to ensure ... community security, and due process for all."' 285

Such sanctuary jurisdictions are popping up not only in blue states, like California, but even in deep red states, like Georgia, Louisiana, and Alabama, as well as in the Rust Belt. 286 Numerous cities-including Austin, Chicago, the District of Columbia, Houston, Los Angeles, Minneapolis, New Orleans, New York, and Santa Clara-have enacted sanctuary laws. While these laws vary from jurisdiction to jurisdiction in scope, "one element they share in common is a commitment to limit the use of local resources in implementing and enforcing federal immigration laws," which these jurisdictions "view as not only infringing on their sovereignty to define local policy, but as being at odds with local policy goals, such as building trust between local law enforcement and communities to more effectively reduce crime and improve public safety." 287

\footnotetext{
2838 U.S.C. $\$ 1373$ (a) (2018).

284 Powell, supra note 255; Exec. Order No. 13768, 82 Fed. Reg. 8799 (Jan. 25, 2017).

285 See Powell, supra note 255; see also S.F., CAL., AdMIN. CODE $\$ \$ 12 \mathrm{H}, 12 \mathrm{I}$ (1989).

286 Jasmine C. Lee, Rudy Omri \& Julia Preston, What Are Sanctuary Cities?, N.Y. TIMES

(Feb. 6, 2017), https://www.nytimes.com/interactive/2016/09/02/us/sanctuary-cities.html? emc=eta1\&_r=0 [https://perma.cc/J633-828G]; see also Powell, supra note 255.

287 Powell, supra note 255.
} 


\section{C. "We the People" and "Sanctuary" Policies}

This Section evaluates in greater detail how today's sanctuary policies are addressing the problem of minority underrepresentation as a political market failure. Subsection III.C.1 provides a typology of sanctuary policies aimed at disentanglement from the federal immigration enforcement apparatus. Subsection III.C.2 examines what motivates these policies, and reflects on the extent to which sub-federal initiatives are directly addressing the problem of minority underrepresentation or merely addressing this problem as a byproduct of more pragmatic concerns.

\section{Typology of Sanctuary Policies Aimed at Disentanglement}

While jurisdictions adopting protective policies have been crudely lumped together under the "sanctuary jurisdiction" label, here I sketch out a typology that describes seven different types of sanctuary policies, along a spectrum of increasing disengagement with Immigration and Customs Enforcement (ICE). ${ }^{288}$ While some of these disentanglement

288 Note that I have drawn this typology from Immigration Legal Resource Center (ILRC). Krsna Avila et al., Immigration Legal Res. Ctr., The Rise of SAnCtuary: Getting LOCAL OfFICERS OUT OF THE BUSINESS OF DEPORTATIONS IN THE TRUMP ERA (2018), https:// www.ilrc.org/sites/default/files/resources/rise_of_sanctuary-lg-20180201.pdf [https://perma.cc/ YGP6-P4PK] [hereinafter ILRC, THE RISE OF SANCTUARY] (surveying 3,015 of the 3,140 countries and county equivalents in the United States). See also Lasch et al., supra note 7, at $1712,1723-36$ (describing similar "types of criminal justice policies that [cities] have adopted to disentangle their law enforcement systems from [] federal immigration enforcement."). The typology adopted by Lasch covers sanctuary cities, not counties (nor states). But summaries of sanctuary policies by the ILRC, Lasch, and others reflect similar categories of policies, regardless of whether at the city, state, or county level (confirming ILRC's categorization).

Note also that the Congressional Research Service describes a useful typology by noting that sanctuary policies are often described as falling under one of three categories:

First, so-called "don't enforce" policies generally bar the state or local police from assisting federal immigration authorities. Second, "don't ask" policies generally bar certain state or local officials from inquiring into a person's immigration status. Third, "don't tell" policies typically restrict information sharing between state or local law enforcement and federal immigration authorities.

Sarah S. Herman, Congressional Res. Serv., R44795, State and local "Sanctuary" POLICIES LIMITING PARTICIPATION IN IMMIGRATION ENFORCEMENT (2017). 
policies began before Trump became president, others were prompted by his election. 289

This typology is geared towards unpacking the extent and degree to which various categories of policies are addressing the problem of minority underrepresentation. Immigrants are subject to federal authority, but often are not permitted to participate in electing representatives who are responsible for passing laws and implementing regulation. The survey here draws on data concerning counties (as opposed to states and cities), as this information (compiled and analyzed by the Immigration Legal Resource Center (ILRC)) is more comprehensive than other studies and is presented in a format that illustrates the degree of disentanglement from the federal immigration enforcement government, which is particularly useful for my analysis concerning tipping problems and norm cascades. 290 The study is based on data from over 3,000 counties. 291

As counties become either increasingly or decreasingly disengaged from the federal immigration enforcement regime (to the extent the policies move in the direction of greater or lesser disentanglement), collectively, these counties could overtime tip the direction norms concerning the treatment of immigrants one way or another. The ILRC illustrates trends that are corroborated through qualitative research concerning the emergence of a network of sanctuary jurisdictions that influence one another. ${ }^{292}$

My description here begins with the category of sanctuary policies that seek the least amount of disentanglement from the federal immigration enforcement apparatus (and are the most common disengagement approach). The subsequent categories discussed move up a spectrum of increasing disengagement with ICE (with data referring to 2017, unless otherwise indicated):

Refusal to enter into $287(\mathrm{~g})$ agreements: Ninety-eight percent of counties did not have a 287(g) agreement with the federal

289 See Lasch et al., supra note 7, at 1723-36.

290 ILRC, THE RISE OF SANCTUARY, supra note 288.

291 Id. I merely summarize this data as a rough indication of various types of sanctuary policies.

292 Villazor \& Gulasekaram, supra note 58. 
government. 293 The $287(\mathrm{~g})$ program involves an optional agreement between the jurisdiction and ICE, which essentially deputizes particular local law enforcement agents to enforce immigration laws. ${ }^{294}$ Only fiftysix (out of the over 3,000) counties had 287(g) agreements with ICE in 2017.295 Because such agreements are optional, it is fairly easy for counties to opt against entering into such agreements.

No ICE detention contract: Nearly ninety-four percent of counties did not have a contract with ICE. 296 Such ICE detention contracts are contracts between ICE and local jails, where ICE pays the jails to hold immigrants in detention during their deportation proceedings. ${ }^{297}$ As with $287(\mathrm{~g})$ agreements, entering into an ICE detention contract is optional (though there are financial incentives to rent out space in local jails to ICE). 298

Limits on ICE detainers (ICE holds): Twenty-four percent of counties have policies against holding individuals beyond their sentence, based on requests from ICE. ${ }^{299}$ Numerically, 764 counties are refusing to cooperate with ICE requests to hold individuals beyond their release date as a way of providing ICE with additional time to take custody of these individuals-a practice numerous officials in these jurisdictions view (and some courts have held) violate the Fourth Amendment rights of those detained. 300

Restricting notifications to ICE about information, such as release dates: Only six percent of counties had policies against sharing information about detainees, such as release dates, with ICE. ${ }^{301}$ ICE asks local agencies to provide advance notice of when immigrants will be released from custody, so that ICE can arrest these individuals upon release. These requests are included in immigration detainers but may be made in other ways. ${ }^{302}$

\footnotetext{
293 ILRC, THE RISE OF SANCTUARY, supra note 288, at 9.

$294 \mathrm{Id}$. at 4.

295 Id. at 9.

296 Id.

297 Id. at 4.

298 Id.

299 Id. at 9.

$300 \mathrm{Id}$. at $9-10$.

301 Id. at 9.

302 Id. at 4.
} 
Limiting ICE access to local jails and ICE interrogations of detainees: Only four percent of counties restrict ICE's access to jails or have put in place safeguards on ICE's ability to interrogate detainees. ${ }^{303}$ Such counties may require a judicial warrant for ICE to access limited areas or adopt procedural protections for imprisoned immigrants so that they can refuse interrogation by ICE agents. 304

Prohibiting inquiries into immigration status and/or place of birth: Only four percent of counties limit their officers from asking individuals about their immigration status. ${ }^{305}$ The overwhelming majority of counties allow these inquiries into immigration status. 306

General bans on participating in immigration enforcement: Only four percent of counties have a general rule against spending time or resources on immigration enforcement, which might include restrictions on participating in joint operations involving immigration enforcement. 307

2. What Motivates Sanctuary Policies and to What Extent Do They Address the Minority Underrepresentation Problem?

This Subsection examines the legal and policy justifications that sanctuary jurisdictions offer to support their protective "sanctuary" policies. These justifications draw from an excellent study by Chris Lasch and other scholars.308 My goal here is to investigate what motivates these policies, and then add to the work of Lasch and his coauthors by reflecting on the extent to which these initiatives directly address the problem of minority underrepresentation or merely address the problem of the rights of immigrants as a byproduct of more pragmatic concerns. This overview of justifications for sanctuary policies starts with the more pragmatic rationales (which address the rights of immigrants as an incidental concern) and then turns to

\footnotetext{
303 Id. at 9 .

$304 \mathrm{Id}$. at 4 .

305 Id. at 9.

306 Id.

307 Id. at 4, 9 .

308 Lasch et al., supra note 7, at 1752-53, 1771.
} 
rationales that are more directly tied to the rights of immigrants as minorities who are underrepresented in the political process.

\section{a. Preserving Local Control over Criminal Justice}

One reason for sanctuary policies is to assert that sub-federal governments should be in control of criminal justice priorities, separate and apart from the federal government's responsibilities over federal immigration enforcement. ${ }^{309}$ Numerous sanctuary policies-in localities ranging from New Haven to Pittsburgh to San Francisco-have asserted a separation between local criminal justice and federal immigration enforcement.310 These “don't enforce” policies bar local criminal law enforcement officials from federal civil immigration enforcement. 311

Drawing the line between these two spheres of authority is supported by the Supreme Court's federalism jurisprudence concerning the Tenth Amendment. For example, the two anti-commandeering cases-New York v. United States ${ }^{312}$ and Printz v. United States ${ }^{313}$-stand for the proposition that the federal government cannot compel state and local governments to use their own resources in carrying out a federal regulatory program. At the same time, criminal justice matters fall within the realm of traditional state and local police powers. ${ }^{314}$

\footnotetext{
309 Id. at 1754.

310 Id. at 1755. As Lasch notes:
}

San Francisco[, CA] noted in adopting its "City and County of Refuge" ordinance in 1989 that state and local officials are under no obligation "to enforce the civil aspects of the federal immigration laws." Pittsburgh[, PA] based its 2004 direction that police "[r]efrain from participating in the enforcement of federal immigration laws" on the rationale that immigration laws "are solely the responsibility of the federal government...." [T]he City of New Haven, Connecticut declared that "[a] community member's potential status as an undocumented immigrant has no relation to the mission or goals of the New Haven Police Department."

Id.

311 The Congressional Research Service describes these "don't enforce" policies as one of several approaches by sanctuary jurisdictions. See HERMAN, supra note 288.

312505 U.S. 144 (1992).

313521 U.S. 898 (1997).

314 See United States v. Morrison, 529 U.S. 598, 601-06, 618 (2000) ("The regulation and punishment of intrastate violence... has always been the province of the States."); United States v. Lopez, 514 U.S. 549, 567 (1995) (noting the prohibition on guns in school zones as "a general police power of the sort retained by the States"). 
As the sanctuary policy in Cooks County, Illinois notes, "the federal government only reimburses part of the costs associated with ICE detainers"315-a classic concern of the Supreme Court's anticommandeering jurisprudence. Moreover, in considering whether ICE has violated the Fourth Amendment (by requesting that states and localities hold immigrants beyond the release dates), at least some courts have found that ICE detainer requests infringe on federalism and Tenth Amendment concerns. ${ }^{316}$ Furthermore, courts have enjoined the President's threat to cut off funds to sanctuary jurisdictions (in the sanctuary jurisdictions executive order) as a violation of, for example, Spending Clause jurisprudence reflecting Tenth Amendment concerns. ${ }^{317}$

\section{b. Enhancing Community Trust and Community Policing}

A second basis for sanctuary policies - which blends pragmatic and minority underrepresentation considerations-is the concern that the entanglement of street-level policing in federal immigration enforcement undermines the trust that is necessary for community members to feel confident in cooperating with local law enforcement. A range of sanctuary jurisdictions-including California, Milwaukee County, and New Haven-have pointed to the importance of building community trust as rationales for disengaging with federal immigration efforts. ${ }^{318}$ Trump's hostile statements and policies toward immigrants

315 Cook County, Ill., Ordinance 11-O-73 (Sept. 7, 2011), http://libguides.law.du.edu/ld.php? content_id=34434520; see also Lasch et al., supra note 7, at 1756 n.270 (discussing similar concerns expressed in the sanctuary policies of California; Philadelphia, PA; and Miami-Dade County).

316 See, e.g., Galarza v. Szalczyk, 745 F.3d 634, 644 (3d Cir. 2014).

317 See, e.g., Cty. of Santa Clara v. Trump, 250 F. Supp. 3d 497 (N.D. Cal. 2017) (granting preliminary injunction and finding likelihood of success on the merits of the plaintiffs' claim that the sanctuary jurisdictions executive order is unconstitutional on the grounds that it violates both horizontal and vertical separation of powers concerns); City \& Cty. of S.F. v. Trump, No. 17-16886, 2018 U.S. App. LEXIS 239 (9th Cir. Jan. 4, 2018) (upholding the district court's permanent injunction on the defunding and enforcement provisions of executive order); Cty. of Santa Clara v. Trump, 267 F. Supp. 3d 1201 (N.D. Cal. 2017) (concluding that the U.S. Attorney General's Memorandum clarifying Trump's executive order does not change the analysis from the PI Order and therefore denying the government's motions for reconsideration); see also cases discussed supra note 98.

318 Lasch et al., supra note 7, at 1761-64. 
have renewed fears in immigrant communities that interaction with local police (and other local authorities) will result in deportation. 319

As many studies have demonstrated, "[c]ommunity trust is critical for effective policing programs." 320 A 2009 Police Foundation national report warned that local law enforcement's cooperation with ICE undermined trust that the local police had developed with

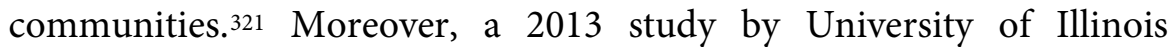
researchers of several counties across the country concluded that police cooperation with ICE's Secure Communities policy had created fear of local law enforcement among Latinos, further undercutting trust. ${ }^{322}$

Such fear "can cause immigrants and individuals in mixed status families to refrain from coming forward as victims of, or witnesses to crime." 323 When reports of sexual assaults and spousal abuse dropped among Latinos, in 2017, the Los Angeles Police Department indicated that "deportation fears may be preventing Hispanic members of the community from reporting when they are victimized." 324

$319 \mathrm{Id}$. at 1761 (explaining that "entangling street-level policing with immigration enforcement erodes community trust").

320 Id.; see generally Doris MARIE PROVIne eT AL., Policing IMMigrants: Local LAW ENFORCEMENT ON THE FRONT LINES (2016).

321 Anita Khashu, Police Found., The Role of local Police: Striking a Balance BETWEEN IMMIgRATION ENFORCEMENT AND CiviL LIBERTIES (2009), https://www.police foundation.org/wp-content/uploads/2015/07/Khashu-2009-The-Role-of-Local-Police.pdf [https://perma.cc/D2JR-SAGT].

322 Nik Theodore, insecure Communities: Latino Perceptions of Police INVOLVEMENT IN IMMIGRATION ENFORCEMENT (2013), http://www.policylink.org/sites/default/ files/INSECURE_COMMUNITIES_REPORT_FINAL.PDF [https://perma.cc/JCT7-WG3W] (linking police involvement in immigration enforcement with Latinos' perceptions about public safety and their reluctance to contact police); see also Marjorie S. Zatz \& Hilary Smith, Immigration, Crime, and Victimization: Rhetoric and Reality, 8 ANN. REV. L. \& SoC. SCI. 141, 150 (2012) (collecting and analyzing empirical research).

323 Lasch et al., supra note 7, at 1762; see also THEODORE, supra note 322 (reporting on the impact of police involvement in immigration enforcement on Latinos' perceptions of public safety and their willingness to contact the police).

324 News Release, L.A. Police Dep't, Decline in Reporting of Crime Among Hispanic Population NR17083ma (Mar. 21, 2017), http://www.lapdonline.org/home/news_view/61998 [https://perma.cc/V7TQ-5AC6] (cited by Lasch et al., supra note 7, at $1762 \mathrm{n.302}$ ). 


\section{c. Averting Unlawful Arrests}

A third ground for sanctuary policies - which also mixes pragmatic and minority underrepresentation considerations-is the concern that unlawful arrests lead to legal and monetary liability. This concern has paved the way for sanctuary policies in Oregon, Colorado, Washington, and California, which have each declared they would no longer consent to ICE detainer requests. ${ }^{325}$ Such concerns about liability, as a result of entanglement with federal immigration enforcement, have grown with the emergence of the crim-immigration regime (discussed above in Section III.B, supra).

Furthermore, three lines of cases cabin the ability of states and localities to participate in making and enforcing immigration law. The first is Arizona v. United States, ${ }^{326}$ which struck down aspects of Arizona's SB 1070 as preempted by federal immigration law. The second line of cases reflects the concern that federal immigration detainers violate the Fourth Amendment. 327 State and local law enforcement officials (such as, prominently, then-California State Attorney General Kamala Harris) have also expressed unease with federal detainer requests and that cooperation with such requests could expose states and localities to liability. ${ }^{328} \mathrm{~A}$ third line of cases "built on the notion, reflected in some sanctuary policies, that civil immigration arrests by local officials must not only be authorized by federal law but by state or local law as well." 329

\section{d. Securing Equal Protection}

A fourth reason for sanctuary policies-which focuses more directly and primarily on the minority underrepresentation problem-is grounded in two concerns based on equal protection: biased policing

\footnotetext{
325 Lasch et al., supra note 7, at 1758-61.

326567 U.S. 387 (2012).

327 See, e.g., Galarza v. Szalczyk, 745 F.3d 634, 645 (3d Cir. 2014); Miranda-Olivares v. Clackamas Cty., No. 3:12-cv-02317-ST, 2014 WL 1414305, at*11 (D. Or. Apr. 11, 2014).

328 See, e.g., Press Release, Office of the Att'y Gen., State of Cal. Dep't of Justice, Attorney General Kamala D. Harris Issues Bulletin to Law Enforcement on Federal Immigration Detainers (June 25, 2014), https://www.oag.ca.gov/news/press-releases/attorney-generalkamala-d-harris-issues-bulletin-law-enforcement-federal [https://perma.cc/YK58-K579].

329 Lasch et al., supra note 7, at 1760 (citing Lunn v. Commonwealth, 78 N.E.3d 1143 (Mass. 2017)).
} 
and discriminatory access to police services. ${ }^{330}$ Many jurisdictionsincluding East Haven, New Orleans, and Vermont-have adopted sanctuary policies aimed at addressing these concerns. ${ }^{331}$

Involving local law enforcement in immigration enforcement can increase the risk of racial profiling in policing. Even where race or ethnicity is not an explicit factor, entangling police in immigration matters can incline officers to use race, ethnicity, and English-language ability as proxies for immigration status, for example, in determining who to stop, question, and investigate. 332

Many disentanglement policies also seek to address discriminatory barriers to accessing police services. When local law enforcement officials are involved in federal immigration policy, policing practices can discourage immigrants and individuals in mixed-status families from cooperating with the police as victims of or witnesses to crime. ${ }^{333}$

Besides the Fourteenth Amendment, ${ }^{334}$ which bars state officials from intentional discrimination (based on, inter alia, race, ethnicity, nationality, an alienage),335 Title VI of the 1964 Civil Rights Act prohibits discrimination in state and local federally funded programs. ${ }^{336}$ Moreover, states and localities often have their own antidiscrimination protections.

\section{e. Encouraging Diversity and Inclusivity}

A fifth basis for sanctuary policies-which is also centered more directly on immigrant/minority rights-is promoting inclusive and diverse communities. ${ }^{337}$ For example, the sanctuary policies in Santa

\footnotetext{
330 Id. at $1764-65$.

$331 \mathrm{Id}$. at 1767.

332 See, e.g., Devon W. Carbado \& Cheryl I. Harris, Undocumented Criminal Procedure, 58 UCLA L. REV. 1543, 1545-47 (2011) (discussing the use of race as a proxy for citizenship).

333 Lasch et al., supra note 7, at 1767-68.

334 U.S. CONST. amend. XIV, $\$ 1$.

335 See, e.g., Korematsu v. United States, 323 U.S. 214 (1944) (holding discrimination against persons of Japanese ancestry to be presumptively unconstitutional, though upholding the internment of such persons); Graham v. Richardson, 403 U.S. 365, 372 (1971) (determining that state classifications based on alienage "are inherently suspect and subject to close judicial scrutiny").

33642 U.S.C. $\$ 2000 d(2018)$.

337 Lasch et al., supra note 7, at 1769-70.
} 
Monica, California reflect these concerns. 338 As discussed above in Section III.B, supra, President Trump has made numerous statements and supported policies that are viewed as undermining inclusivity and even racist. In response to what Santa Monica's mayor described as steps by the Trump administration that failed to "align with our vision of diversity and inclusion," 339 the city adopted a 2017 resolution that rooted a new policing policy in the city's embrace of diversity based on religion, race, national or ethnic origin, gender, and sexual identity or orientation. 340

Promoting inclusive and diverse communities "is related to but distinct from the more legalistic emphasis on equality and nondiscrimination that is seen in some disentanglement policies." 341 The goal of inclusivity is more forward-looking, in contrast to the backwards-looking goal of remediating past discriminatory practices in the criminal justice system and in police services. ${ }^{342}$ By embracing a broader notion of diversity and inclusion, such sanctuary policies tend to be careful not to elevate particular categories of immigrants as "more deserving" than other categories. ${ }^{343}$

\section{The Treatment of Immigrants as a Tipping Problem}

In Part II, I explored the notion, posited by Professor Hale, that to understand climate change, we need to view it as not only a tragedy of the commons, but also as a tipping problem. As he notes, under the standard tragedy of the commons analysis, we may assume that all jurisdictions have similar, if not identical, motives. ${ }^{344}$ However, just as

\footnotetext{
338 Id. at 1769.

339 Resolution Embracing Diversity and Clarifying the City's Role in Enforcing Federal Immigration Law: A Letter from Your Mayor, CITY SANTA MONICA (Mar. 1, 2017), https://beta. smgov.net/strategic-goals/inclusive-diverse-community/diversity [https://perma.cc/KXN4GNWQ].

340 Lasch et al., supra note 7, at 1769-70.

341 Id. at 1769.

342 Id.

343 Id. at 1769 \& n.341 (citing Serin D. Houstin \& Charlotte Morse, The Ordinary and Extraordinary: Producing Migrant Inclusion and Exclusion in US Sanctuary Movements, 11 STUD. Soc. JUST. 27 (2017)).

344 Hale, supra note 111, at 15.
} 
he demonstrates that this is not true in the climate context, ${ }^{345}$ it is also clear from the sanctuary context that jurisdictions are motivated by a variety of policy rationales concerning immigrants. Further, as in the climate context, in the sanctuary context as well, it is clear that certain jurisdictions have been the first and more aggressive movers in adopting sanctuary policies.

Just as Hale explains that certain climate change mitigation steps taken by particular jurisdictions may not be viewed as primarily climate policy per se-but rather as co-benefits (such as reducing local pollution or improving local health) ${ }^{346}$-so too sanctuary jurisdictions adopt policies based on a number of grounds. While some jurisdictions adopt sanctuary policies to advance norms of inclusion, equality, and rule of law, others enact these policies to defend local sovereignty, conserve local resources, and/or avoid legal and monetary liability-rather than to advance the rights of immigrants or address minority representation per se. Those jurisdictions that frame sanctuary policies in these more pragmatic terms (or in ways that combine pragmatism with what we might think of as the civil rights case for immigrants) may be, in fact, ultimately more successful in building alliances with law enforcement and other unlikely bedfellows, which may assist in making these policies more sustainable and more likely to be taken up by other jurisdictions, particularly in red states. To the extent that various disentanglement policies are adopted and even mimicked by other jurisdictions, the norms that underlie these policies could slowly tip in this direction, whether based on the pragmatic local sovereignty objective, effective policing considerations, or the goal of addressing the minority representation problem. The pending lawsuits involving California and the Trump administration regarding sanctuary policy ${ }^{347}$ have thus far largely turned on separation of powers concerns.

345 See discussion supra Section II.C.

346 Hale, supra note 111 , at 16.

347 For the lawsuits that California jurisdictions have filed against President Trump, see supra note 98. The Trump administration has also sued California, challenging three laws that comprise its sanctuary policies, claiming that the California laws "reflect a deliberate effort by California to obstruct the United States' enforcement of federal immigration law." See Katie Benner \& Jennifer Medina, Trump Administration Sues California Over Immigration Laws, N.Y. Times (Mar. 6, 2018), https://www.nytimes.com/2018/03/06/us/politics/justicedepartment-california-sanctuary-cities.html [https://perma.cc/2ADP-BU8G]. At the time of 
While the first wave of sanctuary policies (discussed supra) involved religious leaders who sought to actively prevent federal immigration officials from deporting Central American refugees who faced persecution at home, "[t]oday's sanctuary laws, while bearing the same name, are markedly different." 348 Unlike the early wave, the current wave of sanctuary policies is not actively interfering with federal immigration enforcement. In fact, the exact opposite is true. Sanctuary jurisdictions are stepping aside so that they will not be involved in federal immigration policy at all. As Peter Markowitz notes:

[T] he defining characteristic of these laws is their passivity. They do not direct state officers to take any steps to interfere with federal enforcement efforts. Instead, they dictate that the local police and state officers simply do not assist in the federal government's deportation agenda - that they do nothing. ${ }^{349}$

Therefore, the federalism conflict between jurisdictions such as California and the federal government is more akin to Printz v. United States 350 - where the federal government seeks to enlist states and localities to do its bidding - than Arizona v. United States ${ }^{351}$ - where the state government sought to regulate immigration in a way that was preempted by federal immigration law. Asserting its interest in local sovereignty and criminal justice, California's attorney general, Xavier

this writing, the judge presiding over the case in the Eastern District of California has granted in part and denied in part California's motion to dismiss. United States v. California, No. 2:18cv-490-JAM-KJN, 2018 WL 3361055 (E.D. Cal. July 9, 2018).

348 Peter L. Markowitz, Opinion, Trump Can't Stop the Sanctuary Movement, N.Y. TIMES (Mar. 9, 2018), https://www.nytimes.com/2018/03/09/opinion/trump-california-sanctuarymovement.html [https://perma.cc/4BRK-R7X4].

349 Id.

350521 U.S. 898 (1997) (Justice Scalia sustained a challenge to the federal Brady Act, which required local sheriffs to conduct background checks for gun purchasers, in violation of the anti-commandeering doctrine developed under the Tenth Amendment). Several scholars have analyzed the current sanctuary policies as similar to Printz. See, e.g., Noah Feldman, Sanctuary Cities Are Safe, Thanks to Conservatives, BloOMBERG OpINION (Nov. 29, 2016, 2:52 PM), https://www.bloomberg.com/view/articles/2016-11-29/sanctuary-cities-are-safe-thanks-toconservatives [https://perma.cc/9XYK-8CVQ]; Ilya Somin, More on Federalism, the Constitution, and Sanctuary Cities, WASH. POST (Dec. 12, 2016), https://www.washington post.com/news/volokh-conspiracy/wp/2016/12/12/more-on-federalism-the-constitution-andsanctuary-cities/?utm_term=.31e2997b9a47 [https://perma.cc/L67G-9DJZ].

351567 U.S. 387 (2012). 
Becerra, has noted, "California is in the business of public safety, not in the business of deportations." 352

Even while often framed in pragmatic terms, these policies have the effect of responding to the intimidation, exclusion, and humiliation of federal immigration policy. Furthermore, even though these sanctuary jurisdictions do not have the power-nor are they necessarily seekingto provide legal citizenship to undocumented immigrants, these policies often demonstrate the importance of factors beyond legal citizenship, including broader norms of inclusion, equality, belonging, family unification, respect, and dignity. ${ }^{353}$

\section{CONCLUSION: “Not Your FATHER's FEDERALISM” 354}

As the climate and sanctuary policy case studies in this Article suggest, certain federalism conflicts call for more serious attention to the broader international context, not only because they are inherently transnational, but also because these conflicts represent responses to the types of problems John Hart Ely discussed as a basis for justifying intervention when the political markets systematically malfunction. 355 While Ely's theory was one of judicial review (horizontal separation of powers), I have used his concept of political market failure as a basis for a theory of federalism (vertical separation of powers).

352 Markowitz, supra note 348 (quoting Becerra).

353 Regarding the importance of "belonging" and these related values, see, for example, Chacón, Conceptualizing Belonging, supra note 43; Jennifer Gordon \& R.A. Lenhardt, Rethinking Work and Citizenship, 55 UCLA L. REV. 1161 (2008); Amy C. Torres, Note, "I Am Undocumented and a New Yorker": Affirmative City Citizenship and New York City's IDNYC Program, 86 FORDHAM L. REV. 335 (2017).

354 Professor Heather Gerken on "The Loyal Opposition: Why Our Federalism Is Not Your Father's Federalism”, YALE L. SCH. (Dec. 23, 2013), https://law.yale.edu/yls-today/yale-lawschool-videos/professor-heather-gerken-loyal-opposition-why-our-federalism-not-yourfathers-federalism [https://perma.cc/T39L-UTBD]. Similar to Gerken, I have invoked ways in which governance today differs from governance paradigms of our fathers' generation. Catherine Powell, Gender Indicators as Global Governance: Not Your Father's World Bank, 17 GEO. J. GENDER \& L. 777 (2016), updated and reprinted in Catherine Powell, Gender Indicators as Global Governance: Not Your Father's World Bank, in BIG DATA, BIG Challenges IN Evidence-BASEd PolicymaKing (H. Kumar Jayasuriya \& Kathryn Ritcheske eds., 2015).

355 ELY, supra note 13, at 103. 
This Article examined two forms of political market failures to explain-and support-the turn to lawmaking from below (and above, where possible) the level of nation-state. The first type of political market failure this Article discussed-in the immigration contextresults when minorities are not only underrepresented but also systematically locked out of political power. 356 The second form of political market failure I described-in the climate context-represents the exact opposite problem: influential minorities-in this case, the fossil fuel industry and other powerful economic interests- "dominate the political process and the public has to be protected against legislative capture" 357 or (as with climate policy) regulatory capture (within the executive branch).

I have explored how federalism and international law can, at times, be brought together to address political market failures. Climate policy represents one type of failure, given that federal policy on climate change has been subject to regulatory capture by the fossil fuel industry, as a powerful economic minority. As a result, the Trump administration has begun to roll back several critical elements of the U.S. federal climate policy agenda, indicated its intention to withdraw from the 2015 Paris climate change agreement, and defunded climate change research, thereby creating information asymmetries. This hollowing out of climate regulation permits the fossil fuel industry to externalize the cost of their environmentally-adverse behavior on the rest of the population.

Meanwhile, state and local leaders have told the Trump administration to "get out of the way" and have directly engaged with leaders from other countries as a way of ensuring the United States meets its commitments under the Paris accord, even in the absence of federal leadership. Under the Rio process, international environmental regulation had been top-down, ineffective, and undermined by collective action failures that were driven by regulatory capture. But the Paris Agreement's bottom up and polycentric architecture-which builds in significant roles for subnational (and non-state) actors-is helping to address these failures.

Understanding the problem of climate policy as not simply a tragedy of the commons, but also as a tipping problem, adds greater

$356 I d$.

357 Petersen, supra note 14, at 19. 
clarity. This recognition highlights that state and local climate policy innovation does not merely address a collective action problem based on common interests (or disinterestedness) of similarly situated jurisdictions, but can also incentivize first (and second, and third, etc.) movers to act. By catalyzing greater action over time, state and local adoption of climate change mitigation policies can diffuse regionally, nationally, and even internationally by tipping over into other jurisdictions and ideally paving the way for potential norm cascades.

Applying these insights to the context of sanctuary policies, part of the problem is that unlike climate policy, international standards governing immigrants are weak to nonexistent. Perhaps in part because of this, state and local officials have not sought to engage or enlist international norms.

At the same time, through disentangling their local law enforcement from federal immigration enforcement, sanctuary jurisdictions are poised to address the other type of market failure: minority underrepresentation. Even when the motivations underlying sanctuary policies are pragmatic, as opposed to rooted in social justice concerns, these policies still have the effect of responding to the intimidation, exclusion, and humiliation of federal immigration policy-as such negative impacts in immigrant communities are actually at odds with local law enforcement goals of building trust through community policing and other efforts to secure cooperation and safeguard public safety.

As the two case studies in this Article suggest, by offering checks and balances, federalism is not only a fundamental cornerstone of our constitutional design to prevent abuse and protect individual rights; it can also address fundamental failures in our political process-whether at the federal or sub-federal level. Where international standards are available to help address these failures-particularly for issues that are inherently transnational-federalism can also assist in advancing international law, by facilitating the implementation of international norms locally and by assisting in realizing these norms globally. 